\title{
Metabolic Control of Treg Cell Stability, Plasticity, and Tissue-Specific Heterogeneity
}

\author{
Hao Shi and Hongbo Chi * \\ Department of Immunology, St. Jude Children's Research Hospital, Memphis, TN, United States
}

Regulatory $\mathrm{T}$ (Treg) cells are crucial for peripheral immune tolerance and prevention of autoimmunity and tissue damage. Treg cells are inherently defined by the expression of the transcription factor Foxp3, which enforces lineage development and immune suppressive function of these cells. Under various conditions as observed in autoimmunity, cancer and non-lymphoid tissues, a proportion of Treg cells respond to specific environmental signals and display altered stability, plasticity and tissue-specific heterogeneity, which further shape their context-dependent suppressive functions. Recent studies have revealed that metabolic programs play pivotal roles in controlling these processes in Treg cells, thereby considerably expanding our understanding of Treg

\section{OPEN ACCESS}

Edited by:

Lucy S. K. Walker,

University College London,

United Kingdom

Reviewed by: Shohei Hori

The University of Tokyo, Japan Jinfang Zhu,

National Institute of Allergy and

Infectious Diseases (NIAID),

United States

*Correspondence:

Hongbo Chi

hongbo.chi@stjude.org

Specialty section:

This article was submitted to

T Cell Biology,

a section of the journal

Frontiers in Immunology

Received: 15 August 2019 Accepted: 05 November 2019 Published: 11 December 2019

Citation: Shi H and Chi H (2019) Metabolic Control of Treg Cell Stability, Plasticity, and Tissue-Specific Heterogeneity. Front. Immunol. 10:2716.

doi: 10.3389/fimmu.2019.02716 cell biology. Here we summarize these recent advances that highlight how cell-extrinsic factors, such as nutrients, vitamins and metabolites, and cell-intrinsic metabolic programs, orchestrate Treg cell stability, plasticity, and tissue-specific heterogeneity. Understanding metabolic regulation of Treg cells should provide new insight into immune homeostasis and disease, with important therapeutic implications for autoimmunity, cancer, and other immune-mediated disorders.

Keywords: metabolism, Treg cell, Foxp3, stability, plasticity, tissue-specific heterogeneity

\section{INTRODUCTION}

Regulatory T (Treg) cells are critical for the establishment of peripheral tolerance, with altered Treg cell function leading to autoimmune disease and immunopathology $(1,2)$. Treg cells constitutively express CD25, the $\alpha$ subunit of IL-2 receptor, and require continuous IL-2 signals for homeostasis and function (1-5). The transcription factor forkhead box P3 (Foxp3) is essential for specifying the lineage and suppressive function of Treg cells $(1,2)$. The majority of peripheral Treg cells originate from the thymus and are known as thymus-derived Treg (tTreg) cells (6-8). Treg cells may also differentiate from naïve $\mathrm{CD} 4^{+} \mathrm{T}$ cells in the periphery [called peripherally-derived Treg (pTreg) cells] or in vitro after stimulation in the presence of TGF- $\beta$ and IL-2 (termed iTreg cells) $(6,9,10)$, which are distinguished from tTreg cells by the lack of Helios and neuropilin-1 expression (11-13). In addition, epigenetic modifications of the Foxp 3 locus differ between tTreg and pTreg cells $(6,10)$. How these Treg cells arise and contribute to Treg cell suppressive function in different contexts has remained an important question for the field.

Recent advances have highlighted the important role of metabolism in immune cells, including Treg cells $(14,15)$. Initial studies showed that iTreg cells and conventional effector $\mathrm{T}$ helper cells (Th1, Th2, and Th17) require fatty-acid oxidation (FAO) and glycolysis, respectively, for their proliferation, differentiation, and survival (16). More recent analysis has shown that 
Foxp3 expression likely contributes to these effects (17-19). However, Treg cells in vivo are more metabolically active than conventional naïve $\mathrm{T}$ cells and undergo increased levels of proliferation balanced by apoptosis (20-22). Also, dietary nutrients and metabolites serve as important environmental factors that influence Treg cell function (23). Intracellular metabolites and metabolic pathways also modulate the expression of Foxp3, as well as Treg cell transcriptional programs and functional plasticity (20, 21, 23). In particular, nutrient-fueled mTORC1 activation promotes metabolic reprogramming in Treg cells in vivo, with increased lipogenesis and mevalonate pathway-dependent cholesterol biosynthesis to support Treg cell proliferation and function $(22,24)$. However, inappropriate mTORC1 activation and unconstrained glycolysis in Treg cells lead to decreased Foxp3 expression and reduced Treg cell suppressive activity, indicating that cellular metabolism plays essential roles for regulating Foxp3 stability and Treg cell function $(18,25-27)$. In this review, we summarize the recent advances that have defined how environmental metabolites and nutrients, as well as cell-intrinsic metabolic programs, orchestrate Treg cell function by affecting stability, plasticity, and tissue-specific heterogeneity.

\section{METABOLIC REGULATION OF TREG CELL LINEAGE STABILITY}

Dysfunctional mutations in the Foxp3 gene result in fatal autoimmunity with Scurfy phenotype in mice and IPEX (Immuno-dysregulation, Polyendocrinopathy, Enteropathy, $\mathrm{X}$-linked) syndrome in humans due to altered Treg cell development $(28,29)$. However, maintaining Foxp3 expression is also essential for Treg cell function. The majority of Treg cells are a stable population under steady state or upon transfer into environments that contain $\mathrm{T}$ cells $(30,31)$. More recently, the concept of Treg cell stability, which is defined as the ability to maintain Foxp3 expression and resist acquiring pro-inflammatory effector functions during inflammation, has emerged as a crucial determinant of Treg cell function in selective contexts (32-34). For example, Treg cells display considerable loss of stability in vitro when stimulated with proinflammatory cytokines, including IL-6 and IL-4 $(35,36)$. The resultant Foxp $3^{-}$cells are referred to as "exTreg" cells (35), which are also observed in autoimmune mouse models (37). Adoptive transfer of purified Foxp $3^{+}$Treg cells into lymphopenic recipients that lack conventional $\mathrm{T}$ cells also results in a dramatic loss of Foxp3 expression $(30,37,38)$. These Foxp ${ }^{-}$ cells acquire the expression of inflammatory cytokines and fail to mediate immune suppression $(30,37,38)$. Interestingly, the unstable Treg cells are mostly limited to CD $25^{\text {lo }}$ Foxp $^{+}{ }^{+}$subset, raising the possibility that a small portion of Treg cells are inherently prone to becoming unstable in vivo (30). Further research using fate-mapping mouse models has shown that some exTreg cells are from activated $\mathrm{T}$ cells that have transiently expressed Foxp3 and failed to fully differentiate into Treg cells (39), thus establishing stability as a context-dependent regulator of inflammation and peripheral tolerance.
The molecular mechanisms that prevent the loss of Foxp3 expression have been extensively studied, with the current understanding that Foxp3 expression is maintained through transcriptional, epigenetic and post-translational regulation. First, multiple transcription factors regulate Foxp3 gene expression by directly binding to Foxp3 gene promoter, such as STAT5, NFAT, and Foxo1. In addition, the Foxp3 gene locus contains conserved non-coding sequence (CNS) elements, which recruit transcription factors to regulate gene expression (40-42). For example, CNS1 responds to TGF- $\beta$ and recruits Smad3 (43); CNS2 recruits STAT5 (35), NFAT (44), RUNX (45), and CREB (46), among others; and the NF- $\kappa \mathrm{B}$ signaling component c-Rel binds to CNS3 (47). Second, CNS2 contains a Treg cell-specific demethylated region (TSDR) (48), which is largely demethylated in tTreg cells and partially methylated in iTreg or pTreg cells $(41,42,49,50)$. The demethylated TSDR allows for recruitment of transcription factors, such as Foxp3 itself, CREB, and Ets-1, to stabilize Foxp3 expression $(46,51,52)$. Third, acetylation, phosphorylation and ubiquitination have been identified to orchestrate Foxp3 protein stability (42). In particular, recent studies have established a critical role of metabolism in regulating Treg cell stability through interplaying with the established mechanisms of transcriptional, epigenetic, and post-translational control of Foxp3 expression (Figure 1). Below, we summarize the progress in metabolic regulation of Treg cell stability. We first discuss how environmental nutrients and metabolites influence Foxp3 stability. Then, how intrinsic cellular metabolism modulates Treg cell lineage identity is detailed. Finally, the signaling mechanisms for establishing metabolism-dependent control of Foxp3 expression are described.

\section{Environmental Nutrients and Metabolites}

Multiple dietary nutrients, vitamins, and metabolites can directly modulate Foxp3 expression in Treg cells. Among them, the vitamin A metabolite all-trans retinoic acid (RA), produced by specific dendritic cell (DC) subsets, directly and indirectly modulates Foxp3 expression (53-56). RA directly increases the activation of extracellular-related kinase (ERK) signaling to promote Foxp3 expression (56). RA also increases histone methylation and acetylation of the promoter and CNS at the Foxp3 gene locus (56). RA indirectly promotes TGF- $\beta$-mediated Foxp $3^{+}$Treg cell conversion by relieving inhibition from CD $44^{\text {hi }}$ memory T cells (57). Specifically, CD $44^{\text {hi }}$ memory T cells release a series of inflammatory cytokines, such as IL-4, IL-21, and IFN $\gamma$, which act synergistically to inhibit TGF- $\beta$-induced Foxp3 expression; however, RA suppresses these pro-inflammatory cytokine programs and therefore stabilizes Foxp3 expression (57). RA can also prevent the loss of FOXP3 expression during human Treg cell expansion and in inflammation, with superior efficacy as compared with rapamycin (an mTORC1 inhibitor) that is known to promote stable Foxp3 expression (55).

In addition to vitamin $\mathrm{A}$, vitamins $\mathrm{C}$ and $\mathrm{D}$ have been directly linked to the regulation of Foxp3 expression. Recent research has established roles for vitamin $\mathrm{C}$ in immune cell function, including its ability to stabilize Foxp 3 expression by demethylation of CNS2 region in iTreg cells $(58,59)$. Specifically, the CpG motifs of 


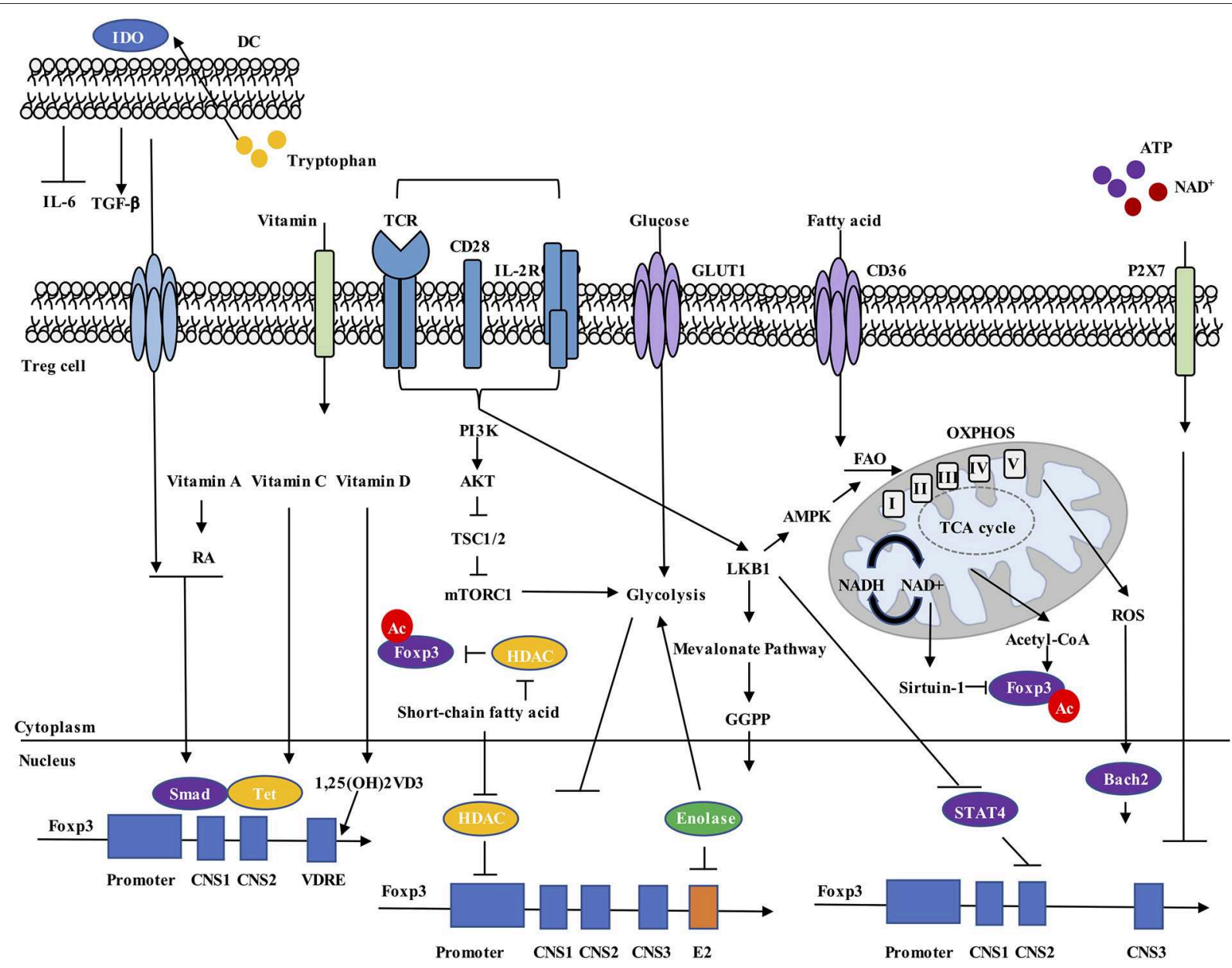

FIGURE 1 | Metabolic regulation of Foxp3 expression. Environmental metabolites, intracellular metabolic intermediates, and signaling pathways all regulate Foxp3 expression in Treg cells. (1) Dendritic cells (DCs) express IDO, drive tryptophan metabolism to promote TGF- $\beta$ and inhibit IL-6 production, and increase Foxp3 ${ }^{+}$Treg cell generation. (2) Vitamin A metabolite RA, together with TGF- $\beta$-induced Smad activation, increase Foxp3 expression. Vitamin $C$ stabilizes Foxp3 expression through maintaining demethylated state of Foxp3 CNS2 region by Tet methylcytosine dioxygenase. Vitamin $\mathrm{D}_{3}$ metabolite $1,25(\mathrm{OH})_{2} \mathrm{VD} 3$ increases Foxp3 gene expression by binding to VDRE region. (3) Extracellular ATP and NAD+ released by cell lysis activate the P2X7 receptor and induce Treg cell instability. (4) Increased cellular ratio of metabolites NAD ${ }^{+}$NADH activates the deacetylase activity of Sirtuin-1 and destabilizes Foxp3 protein, while acetyl-CoA increases acetylation level of Foxp3 protein and promotes its stabilization. (5) ROS promotes SENP3-driven Bach2 deSUMOylation and nuclear localization, thus stabilizing Foxp3 expression. (6) Short-chain fatty acids stabilize Foxp3 expression, possibly by inhibiting HDAC-mediated suppression of Foxp3 gene expression and Foxp3 protein deacetylation. (7) Unconstrained activation of mTORC1 and glycolysis inhibit Foxp3 expression and reduce suppressive activity of Treg cells. (8) LKB1 prevents STAT4 activation and binding to CNS2 of Foxp3 gene, thus preventing the destabilization effect by inflammatory cytokines. LKB1 also regulates Foxp3 expression through activation of mevalonate pathways. RA, all-trans retinoic acid; VDRE, vitamin D response element; CNS2, conserved non-coding sequence 2; NAD, nicotinamide adenine dinucleotide; ROS, reactive oxygen species; HDAC, histone deacetylase.

CNS2 in iTreg cells are partially methylated $(48,60)$, and CNS2 becomes demethylated after treatment with vitamin $\mathrm{C}$, whose effect is mediated by the Tet family demethylase proteins $(58,59)$. Deletion of Tet2 blocks the demethylation effect of vitamin C $(58,59)$. Deletion of Tet $2 /$ Tet 3 in Treg cells indeed leads to unstable Foxp3 expression $(61,62)$. Vitamin D3 is synthesized in the skin in response to ultraviolet light or acquired from diet, and the vitamin D3 metabolites, 25-dihydroxyvitamin D3 $\left[25(\mathrm{OH}) \mathrm{VD}_{3}\right]$ and the active form $1,25(\mathrm{OH})_{2} \mathrm{VD}_{3}$, can promote Foxp3 expression in TCR and IL-2-activated CD4 ${ }^{+} \mathrm{T}$ cells (63, 64). Subsequent analysis has revealed the presence of vitamin $\mathrm{D}$ response element (VDRE) in the intronic conserved CNS region $(+1714$ to +2554$)$ of the human FOXP3 gene as a functional enhancer, which underlies how vitamin D3 induces FOXP3 expression (65). However, the specific transcriptional regulation mechanisms of VDRE on FOXP3 gene remain to be ascertained.

Other metabolites also regulate Foxp3 expression in Treg cells, such as those from tryptophan and purine metabolism. DCs that express the enzyme indoleamine 2,3-dioxygenase (IDO) can catabolize tryptophan. The IDO-dependent catabolic program subsequently induces Foxp $3^{+}$Treg cell generation through inhibition of IL- 6 production by DCs $(66,67)$. Mice treated with the tryptophan metabolite 3 -hydroxyanthranilic acid 
(3-HAA) increase expression of TGF- $\beta$ in DCs, display increased percentage of Treg cells, reduced frequencies of Th1 and Th17 cells, and ameliorated development of experimental autoimmune encephalomyelitis (EAE) (68). Tryptophan also serves as the precursor for de novo nicotinamide adenine dinucleotide $\left(\mathrm{NAD}^{+}\right.$) synthesis (69), which is also regenerated from NADH by reduction of pyruvate to lactate during activation of glycolysis. The $\mathrm{NAD}^{+} / \mathrm{NADH}$ ratio directly regulates the activity of deacetylase Sirtuin-1 (70). Since acetylation improves Foxp3 protein stability (71), Sirtuin-1 post-translationally impairs the acetylation and stability of Foxp3 (72). Foxp3 expression is also regulated by metabolites from extracellular purine metabolism, which orchestrates the balance of proinflammatory ATP and anti-inflammatory adenosine. Extracellular ATP and $\mathrm{NAD}^{+}$that are released by cell lysis or non-lytic mechanisms during cell damage and inflammation can activate the $\mathrm{P} 2 \mathrm{X} 7$ receptor and induce $\mathrm{T}$ cell death. Treg cells highly express $\mathrm{P} 2 \mathrm{X} 7$ receptor, which upon activation can limit Foxp3 stability and enhance Treg cell conversion into Th17 cells (73). Intriguingly, Treg cells express high levels of the ectonucleotidases CD39 and CD73 on the surface, which convert excess extracellular ATP into immunosuppressive adenosine to relieve the harmful effect of extracellular ATP and increase their suppressive function (74). The results suggest that purine metabolism could be important for Treg cells to maintain stability. Overall, we still know little about how nutrients and metabolites regulate Treg cell stability, especially in vivo, which may be uncovered by using metabolomics techniques.

\section{Cellular Metabolism}

Cellular metabolism is also closely related to Treg cell stability. Compared to Th1, Th2, and Th17 cells, Treg cells are less reliant on glycolysis and use mitochondrial metabolism and oxidative phosphorylation (OXPHOS) for energy production (16). In vitro studies reveal that expression of Foxp3 reprograms $\mathrm{T}$ cell metabolism by suppressing glycolysis and enhancing OXPHOS $(17,18)$. The effector molecules CTLA4 and PD1 on Treg cells also suppress glycolysis in $\mathrm{T}$ cells $(75,76)$. Several studies have indicated that elevated glycolysis may be detrimental to Treg cell induction, as inhibition of glycolysis promotes the induction of Foxp3 expression in response to TGF- $\beta$ and IL-2 stimulation $(77,78)$. In addition, deletion of HIF- $1 \alpha$, a transcription factor that can promote glycolysis, also leads to increased Foxp3 induction (78). In vivo, transgenic mice expressing Glut1 (Glut1-tg) have a greater proportion of $\mathrm{CD} 25^{\text {lo }} \mathrm{Foxp} 3^{+}$cells than those from wild-type mice (18). Further analysis has demonstrated that Glut1-tg expression reduces Foxp3 expression in iTreg cells and in vivo during intestinal inflammation. Analysis of key metabolism-related proteins has also illustrated that excessive glycolysis can lead to reduced Treg cell stability. For instance, c-Myc promotes glycolysis in $\mathrm{T}$ cells (79), whose activity was recently shown to be inhibited by autophagy to maintain Treg cell stability (25). Furthermore, specific deletion of phosphatase and tensin homolog (PTEN) in Treg cells also leads to PI3K/Akt-mediated hyperactivation of glycolysis, a greater proportion of $\mathrm{CD} 25^{\mathrm{lo}} \mathrm{Foxp} 3^{+}$cells similar as Glut1-tg mice, and increased methylation of the TSDR region of Foxp3 gene $(26,27)$. These studies together demonstrate that unrestrained glycolysis results in reduced Treg cell stability. Of note, a recent study in human Treg cells has demonstrated that the glycolytic enzyme Enolase-1 binds to the FOXP3 promoter and its CNS2 region, and represses the transcription of a splice isoform containing Exon-2 (FOXP3-E2), which is important for Treg cell suppressive activity (80). Glycolysis drives Enolase-1 to translocate out of nucleus and relieves the repression of transcription of FOXP3-E2 (80). Moreover, recent studies have established that glycolysis also increases Treg cell migration (81). It is reasonable to speculate that Treg cells precisely calculate and balance cellular glucose consumption, where heightened glycolysis increases Treg cell proliferation or migration to fill the niche and expand the pool in vivo, but this activity is balanced by other metabolic programs (for example, OXPHOS) to maintain lineage stability and suppressive activity. Intriguingly, TLR signals in Treg cells have been shown to promote PI3K/Akt signaling, and increase glycolysis and proliferation, while reducing suppressive function (18). Thus, we propose that Treg cell stability and function are under precise control of glycolysis. However, the detailed mechanisms whereby glycolysis interplays with Foxp3 expression remain to be ascertained.

As noted above, several recent studies have demonstrated crucial roles for mitochondrial metabolism and OXPHOS for Treg cell suppressive activity both at steady state and in the tumor microenvironment (82-85). Treg cells display greater mitochondrial mass and higher levels of reactive oxygen species (ROS) compared with conventional T cells (82), likely produced from OXPHOS. ROS is reported to increase the SUMOspecific protease 3 (SENP3) stabilization, and trigger Bach2 deSUMOylation (86). DeSUMOylation of BACH2 prevents its nuclear export, thus maintaining Foxp3 expression and Treg cell stability (86). Moreover, Treg cell-specific deletion of mitochondrial transcription factor A (Tfam) (promotes synthesis of mitochondrial DNA-derived proteins), can destabilize Foxp3 expression, which is associated with enhanced methylation in the TSDR of Foxp 3 locus in Treg cells under inflammatory contexts (87), whereas Tfam is dispensable for Foxp3 stability in the absence of inflammation (85). These findings are in agreement with a recent study that showed specific deletion of mitochondrial complex III impairs suppressive function without altering Foxp3 expression in Treg cells (84). Thus, OXPHOS in Treg cells seems to enforce Treg cell function independently of regulating their stability.

A growing area of interest is the regulation of OXPHOS by extracellular nutrients in Treg cells. As upregulation of glycolysis can be detrimental to Treg cell function, several studies have instead focused on the roles of fatty acids and FAO for the regulation of Treg cell function and stability. FAO involves the degradation of fatty acids by the sequential removal of two-carbon units from the acyl chain to produce acetyl-CoA, which enters the mitochondrial tricarboxylic acid (TCA) cycle to regulate mitochondrial OXPHOS and other functions. Short-chain fatty acids can indeed stabilize Foxp3 expression, possibly by inhibiting the expression of histone deacetylases (HDACs), such as HDAC6 and HDAC9 that can 
destabilize Foxp3 protein stability (88). However, the roles of HDACs is likely complex, as they may also orchestrate acetylation status of other transcription factors, like STAT5 that induces and sustains Foxp3 gene expression (89). Other studies have also revealed that acetyl-CoA levels contribute to Foxp3 expression through the post-translational control of protein acetylation and protein stability in Treg cells (90). However, FAO may serve only context-dependent roles in Treg cells. Carnitine palmitoyl-transferase 1A (Cptla) is a protein found in the outer mitochondrial membrane that catalyzes the esterification of long-chain acyls with carnitine to form acylcarnitine and is considered to be the rate-controlling for longchain FAO. The frequency and total number of Treg cells in mice lacking Cpt1a in $\mathrm{CD}^{+}$cells or in Foxp3 ${ }^{+}$Treg cells are comparable in different tissues (91). Ex vivo-isolated Treg cells lacking Cpt1a display normal Foxp3 expression levels and similar mitochondrial oxidative capacity relative to their wildtype counterparts. As the study is unable to rule out the possible role of medium-chain and short-chain fatty acids, the effects of fatty acid metabolism on Foxp3 expression and stability require further investigation.

\section{Metabolic Signaling}

Several signaling pathways that impact $\mathrm{T}$ cell metabolism have been identified. Among them, PI3K/Akt and LKB1/AMPK (AMP-activated protein kinase) signaling pathways play central roles. PI3K catalyzes the conversion of PtdIns-4,5- $\mathrm{P}_{2}$ (PIP2) toward PtdIns-3,4,5- $\mathrm{P}_{3}$ (PIP3) and activates kinases with Pleckstrin homology (PH) domains, most notably Akt (92). PI3K/Akt signaling is activated by upstream TCR and IL-2 signaling in Treg cells (93). Akt also directly phosphorylates the Foxo (Foxol or Foxo3a) transcription factors and blocks their nuclear translocation (94). Stable tTreg cells display hypoactivation of Akt, resulting in enhanced nuclear Foxo abundance on the promoter regions of Foxp3, leading to stable Foxp3 expression (95-97). These observations are consistent with those showing that Foxo activity limits glycolysis in $\mathrm{T}$ cells via impairing c-Myc function (98). Ligation of neuropilin-1 by Sema4a promotes Treg cell stability through PTEN-dependent inhibition of Akt activity (99), which facilitates Foxo nuclear localization and thereby increases Foxp3 expression (99). These results indicate an indispensable role of the Akt/Foxo pathway in orchestrating Treg cell stability.

Akt can also indirectly affect the activation of the mTOR complexes, mTORC1 and mTORC2, which integrate upstream metabolic signals for metabolic programming (100). Akt phosphorylates TSC2 to relieve TSC complex inhibition on mTORC1, which is a critical driver of glycolysis through augmenting the expression of glucose transporters, such as Glut1, or transcription factors, including c-Myc $(100,101)$. mTOR inhibition by rapamycin drastically enhances TGF- $\beta$ induced Foxp3 expression in vitro (102), indicating that Treg cells require low mTORC1 activity for induction of Foxp3 expression. However, deletion of mTORC1 in Foxp $3^{+}$Treg cells does not affect Foxp3 expression on a per cell basis in vivo (22), whereas conditional deletion of TSC1 in Treg cells leads to impaired Foxp3 expression and heightened IL17 production under inflammatory conditions (103). Thus, unconstrained mTOR activation can have deleterious impacts on Treg cell stability. Several studies have also investigated the role of mTORC2 in Treg cell stability and function. Rictor (the obligate protein for mTORC2) deletion in Treg cells results in no obvious abnormalities (22). Rictor-deficient $\mathrm{T}$ cells also retain their capacity to become Foxp $3^{+}$iTreg cells $(104,105)$. Thus, mTORC2 has a less dominant function in vivo and in vitro than that of mTORC1 at steady state. However, upon Foxp3 deficiency, mTORC2 is responsible for augmented aerobic glycolysis and OXPHOS in Treg cells, and deletion of Rictor could restore the suppressive activity of Foxp3-deficient Treg cells (106). TCR and IL-2 are two of the most important upstream drivers for mTORC1 activation in Treg cells. Co-stimulation with TCR and IL-2 in vitro can relieve the suppression of PTEN on Akt-mTOR activation in Treg cells, reverse the anergic state of freshlyisolated Treg cells and promote their proliferation (107). How Treg cells maintain mTOR activation-mediated expansion and prevent unconstrained mTOR activation-induced instability in vivo warrants further investigation. However, it should be noted that hormones, such as leptin, may allow for temporal tuning of mTOR activation to promote appropriate expansion of Treg cells without affecting Foxp3 stability (108). Thus, a key future direction will be to dissect the upstream metabolic inputs that promote mTOR activity in Treg cells, toward understanding the effect of environmental cues and the mechanisms by which they are transmitted to impact Treg cell function.

The AMPK pathway, which is activated in response to cellular stress (e.g., AMP/ATP ratio), suppresses mTOR signaling and promotes mitochondrial OXPHOS rather than glycolysis (109-111). The AMPK agonist AICAR (5-aminoimidazole4-carboxamide ribonucleotide) strongly enhances Treg cell expansion (112). Activation of AMPK signaling by metformininduced FAO also promotes Treg cell generation in vivo (16). iTreg cells have high levels of activated AMPK and FAO (16), likely due to the ability of AMPK to modulate Cptla activity and increase fatty acid import into mitochondria for $\beta$-oxidation (110). The serine-threonine kinase LKB1 is activated in response to TCR signals and can directly phosphorylate and activate AMPK $(111,113)$. LKB1 promotes mitochondrial fitness and FAO in Treg cells (113); however, these events appear to be AMPK-independent (113-116), suggesting other downstream LKB1 targets as important regulators of metabolic programming in Treg cells. In addition, recent analysis of LKB1-deficient Treg cells demonstrates that LKB1 enhances Foxp3 expression by preventing CNS2 methylation (114), and by activation of the mevalonate pathway that generates many metabolites, including cholesterol and the isoprenoid geranylgeranylpyrophosphate (GGPP) (115). Specifically, LKB1 prevents STAT4 activation and binding to CNS2, thus maintaining Foxp3 stability in response to STAT4-inducing inflammatory cytokines (114). Moreover, mevalonate or GGPP treatment restores the function and stability of LKB1-deficient Treg cells (115). The precise mechanisms that control AMPK and LKB1 activation in Treg cells require further study. 


\section{SHAPING TREG CELL PLASTICITY BY METABOLISM}

Unlike loss of stability, "plastic" Treg cells tend to retain Foxp3 expression, but acquire the expression of transcription factors associated with effector $\mathrm{T}$ cell programs (called Th-like Treg cells). Plasticity is essential for Treg cells to exert specific suppressive activity toward selective types of inflammation and various environmental conditions. Specifically, Treg cells express the transcription factor T-bet to suppress type- 1 inflammation, and acquire IRF4 and STAT3 to inhibit type- 2 and type-17 inflammation, respectively (117-120). Gata3 expression by Treg cells is also important for suppression of type-2 inflammation in barrier sites like the skin and intestine (121, 122). In other studies, loss of Gata3 in Treg cells is associated with reduced Foxp 3 expression and increased expression of ROR $\gamma \mathrm{t}$ during inflammation $(123,124)$, while co-deletion of T-bet and Gata3 directly leads to severe autoimmune-like disease and impaired Treg cell function (125). Moreover, Bcl6 is induced to generate T-follicular regulatory (Tfr) cells, which control germinal center responses (126-128). It is important to note that subsequent studies have revealed that these Thlike Treg cells may display impaired suppressive function in certain contexts (129-132). Th-like Treg cells normally display demethylated state on Foxp3 TSDR region (129). However, in certain inflammatory contexts, the epigenetic status could be altered by the presence of environmental cytokines, which may allow these cells to express proinflammatory cytokines (132). Thus, it remains unclear why Th-like Treg cells are suppressive in some contexts but pro-inflammatory in others. Notably, there is considerable controversy about whether instability is a separate cellular state from plasticity $(33,34)$. Both instability and plasticity have been observed in various autoimmune diseases in mice and humans, but the mechanistic connection between instability and plasticity in disease settings remains incomplete. Whether Th-like Treg cells represent a transient stage toward becoming Foxp $3^{-}$Treg cells requires further investigation.

The best characterized Th-like Treg cells are Th1-like Treg cells, which express T-bet and CXCR3 (117). Th1-like Treg cells have been observed in autoimmune (Sjögren syndrome) (133) and tumor models. In fact, increased expression of IFN$\gamma$ by Treg cells can markedly improve checkpoint blockade therapy $(134,135)$. The dominant effect of IFN- $\gamma^{+}$Treg cells in these tumor models indicates that these cells not merely lose suppressive function but gain anti-tumor effector activity. In humans, IFN- $\gamma^{+}$Treg cells are found in patients with relapsing/remitting multiple sclerosis (RRMS), type 1 diabetes and autoimmune hepatitis $(129,132,136)$. In vitro, IL-12 stimulation induces T-bet, CXCR3, CCR5, and IFN- $\gamma$ expression in Treg cells, which maintain a demethylated TSDR and FOXP3 expression $(129,131)$. These results underscore a critical role of IL-12 signaling in promoting Th1-like Treg cell generation. The observations are consistent with those that T-bet expression is further induced in type- 1 inflammation, but studies using mouse models have shown that T-bet and IFN- $\gamma$ are not co-expressed in Th1-like Treg cells as Th1

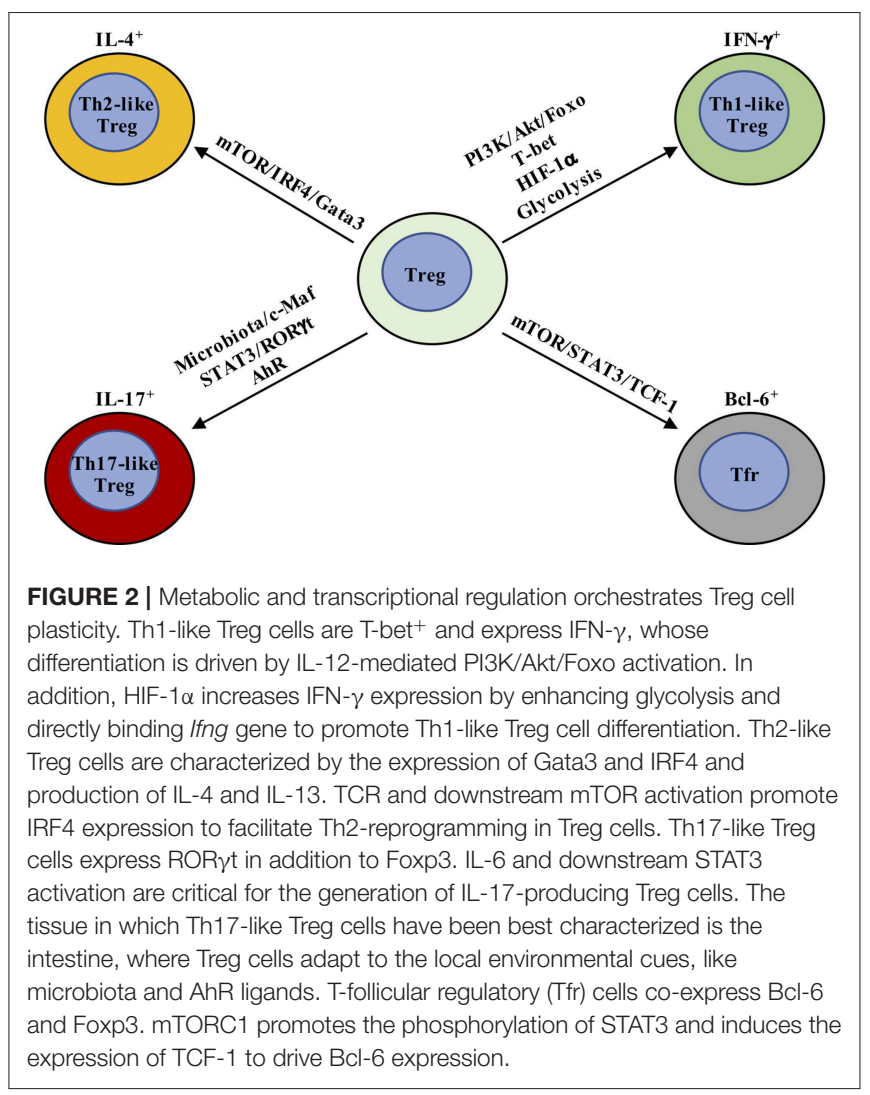

cells, possibly due to delayed induction of IL-12 receptor component IL-12R $\beta 2$ and IL-12 signaling (117). Thus, how IL12 can differentially regulate Th1-like programming in Treg cells as compared with Th1 cells remains an interesting question to address.

Metabolic pathways are emerging regulators of Treg cell plasticity (Figure 2) (95, 113, 131, 137). For instance, $\mathrm{PI} 3 \mathrm{~K} / \mathrm{Akt} /$ Foxo signaling plays an important role in regulating IL-12-induced IFN- $\gamma$ production in Treg cells (131), but also promotes metabolic programming as discussed below. Freshlyisolated IFN- $\gamma^{+}$Treg cells display increased expression of Akt1 and decreased expression of Akt2 and PTEN (131). In vitro, IL-12 directly activates PI3K/Akt/Foxo pathway to drive Th1 polarization in Treg cells (131). Moreover, Foxo1 can be recruited to a regulatory element upstream of the transcriptional start site of Ifng gene. Treg cell-specific deletion of Foxol leads to upregulation of Ifng gene expression and increased IFN $\gamma^{+}$Treg cells $(95,96)$. Notably, the suppressive activity of Foxo1-deficient Treg cells is mostly corrected by blockade of PI3K/Akt pathways (95). As described above, decreased Foxo activity is correlated with increased glycolysis in T cells (98), and increased glycolysis is recently reported to promote Th1 cell differentiation by epigenetic regulation of Ifng gene locus (138), suggesting that Treg cells may also adopt similar interplay between metabolic and epigenetic regulation to polarize Th1-like differentiation. In further support of this notion, a recent study has reported that deficiency of the E3 ubiquitin ligase VHL causes Treg cells to 
adopt an IFN- $\gamma^{+}$Th1-like Treg cell program (139). This event is mediated through both a shift in glycolytic programming driven by HIF- $1 \alpha$, and increased binding of HIF- $1 \alpha$ to the Ifng gene, further strengthening the link between glycolysis and IFN- $\gamma^{+}$ Treg cell generation. Whether metabolites or key glycolytic enzymes promote the generation of Th1-like Treg cells needs further investigation.

For Th2-like Treg cells, both aberrant and beneficial phenotypes have been observed. Toward the former, programming of Th2-like Treg cells is associated with compromised suppressive function in respiratory syncytial virus (RSV) infection and food allergy mouse models $(140,141)$. Treg cell-specific deletion of E3 ubiquitin ligase Itch also leads to generation of Th2-like Treg cells that can drive Th2-related pathologies (142). As noted above, Th2-like Treg cells are characterized by expression of Gata3 and IRF4, as well as production of IL-4 and IL-13 (140-142). Th2-like programming can be induced by IL-4R signals that promote Gata3 expression $(140,141)$. Additionally, TCR signals induce IRF4 expression in Treg cells, and mice with Treg cell-specific deletion of IRF4 develop type-2 inflammation, as IRF4 expression suppresses expression of pro-inflammatory Th2-specific genes in Treg cells (119). IRF4 can also form complex with Foxp3 to regulate the transcriptional program and generation of effector Treg (eTreg, $\left.\mathrm{CD} 4^{+} \mathrm{CD} 2 \mathrm{~L}^{-}\right)$cells $(119,143)$. mTOR functions downstream of TCR to drive IRF4 expression to control Th2 inflammation (85). Moreover, defects in metabolic reprogramming caused by LKB1 deletion in Treg cells are associated with impaired suppression of Th2 immunity (113). These results together suggest that metabolic pathways may have a great impact upon Th2-like Treg cells, although the precise mechanisms have not been defined.

Th17-like Treg cells co-express ROR $\gamma \mathrm{t}$ with Foxp3 (144, 145 ) and can be generated in the periphery (145). Also, under inflammatory conditions, ROR $\gamma \mathrm{t}^{+}$Treg cells can be generated from tTreg cells (146). These IL-17-producing Treg cells retain suppressive function $(144,145,147)$. IL-6 and downstream STAT3 activation, as well as IL-23, IL-1 $\beta$, and IL-21, are critical for the generation of IL-17-producing Treg cells (148150). The tissue in which Th17-like Treg cells have been best characterized is the intestine, where Treg cells adapt to the local environmental changes through functional and phenotypic reprogramming as discussed more below. In addition, as a central coordinator of metabolism in T cells, mTOR also controls Treg cell polarization into other functionally plastic subpopulations, such as Tfr cells in the germinal center (137). Mechanistically, mTORC1 promotes the phosphorylation of the transcription factor STAT3 and induces the expression of the transcription factor TCF-1 to drive Bcl-6 expression. These results together indicate that metabolism plays a critical role in modulating Treg cell plasticity. However, the limitations of low cell numbers and inability to isolate Th-like Treg cells based on surface markers impede analysis of how metabolism controls their homeostasis and function. The development of single cell metabolomics (151, $152)$ and new fate-mapping genetic tools $(118,125)$ could help understand the metabolic regulation of Th-like Treg cells in the future.

\section{METABOLIC ADAPTION IN TISSUE TREG CELLS}

An emerging concept is that Treg cells found in nonlymphoid organs, including adipose tissue, intestine, and tumors, display marked tissue-specific heterogeneity. Tissuespecific transcriptional programs, possibly orchestrated by unique transcription factors, such as PPAR $\gamma, \operatorname{ROR} \gamma t$, and Gata3, facilitate the ability of tissue-resident Treg cells to maintain tissue homeostasis. Non-lymphoid and tumor tissues have dramatic differences in their metabolic environments than secondary lymphoid organs, thus suggesting differences in their nutrient and intracellular metabolic requirements. Notably, Treg cells in non-lymphoid organs and tumor tissues are largely eTreg cells. mTOR has been identified as a critical driver for the generation and function of eTreg cells in both lymphoid and non-lymphoid tissues $(85,153)$, which acts downstream of TCR signals to drive IRF4 expression and mitochondrial metabolism, facilitating eTreg cell generation. The result further underscores a central role of metabolism in modulating tissue Treg cell heterogeneity and homeostasis (Figure 3).

\section{Adipose Tissue}

Among different types of adipose tissues, visceral adipose tissue (VAT) is enriched for Treg cells (hereafter called VATTreg cells) whose major nutrient source seems to be fatty acids derived from the environment. VAT-Treg cells display a distinct gene expression signature compared to Treg cells from secondary lymphoid organs (154). Peroxisome proliferatoractivated receptor gamma (PPAR $\gamma)$ expression is critical for establishing the unique VAT-Treg cell transcriptional program and homeostasis (155). Indeed, mice that specifically lack PPAR $\gamma$ in Treg cells have a significantly reduced population of VAT-Treg cells, but not Treg cells in other organs. The increased expression of PPAR $\gamma$ promotes fatty acid metabolism and stimulates the accumulation and suppressive activities of the VAT-Treg cells (155). Moreover, VAT-Treg cells express CD36, a receptor that facilitates uptake of long-chain fatty acids and contributes to lipid accumulation in contexts of highfat diets and obesity (155). Obese mice display significantly decreased VAT-Treg cells, which may be partly explained by the heightened leptin signaling $(108,156)$. Leptin may be produced by adipose cells (157). VAT-Treg cells express leptin receptor, receive increased leptin secretion from VAT of obese mice and decrease their proliferation and number, suggesting that leptin may be an important environmental cue in the adipose tissue for modulating Treg cells (21). This observation is consistent with other studies that identified a central role of leptin in inhibiting Treg cell proliferation and resulting in Treg cell anergy in vitro $(108,156)$. In addition, a recent report has found that the enzyme hydroxyprostaglandin dehydrogenase (HPGD) is highly expressed in VAT-Treg cells, which is dependent on PPAR $\gamma$. HPGD catabolizes prostaglandin $\mathrm{E}_{2}\left(\mathrm{PGE}_{2}\right)$ into the metabolite 15-keto $\mathrm{PGE}_{2}$ to suppress conventional $\mathrm{T}$ cell activation and proliferation (158). These results together demonstrate that Treg cells adapt to unique VAT environments for their homeostasis and function. 


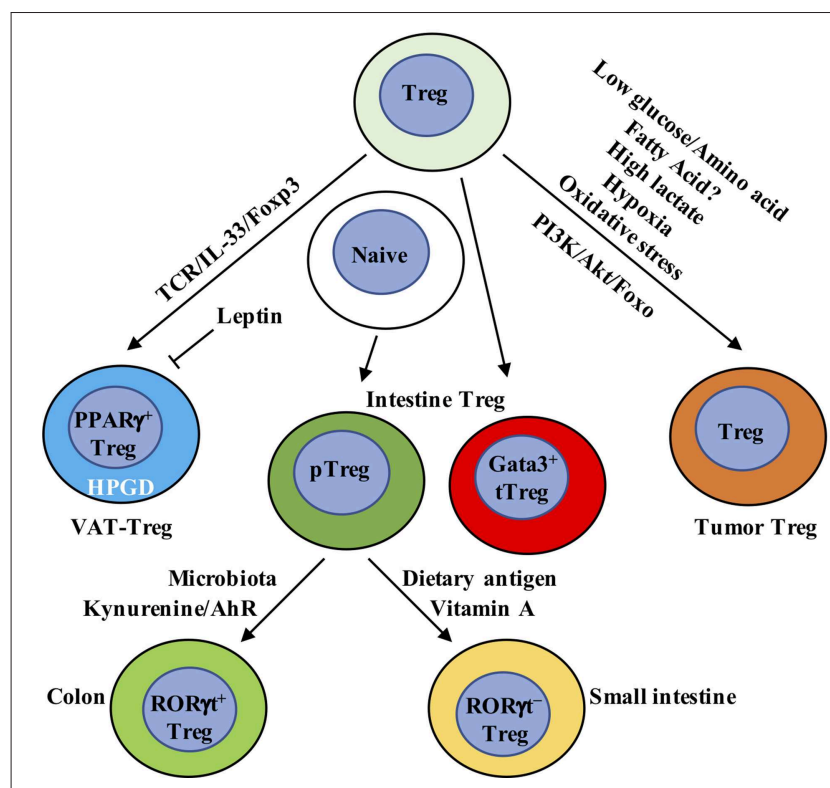

FIGURE 3 | Metabolic and transcriptional adaption in tissue Treg cells. VAT-Treg cell accumulation is dependent upon TCR, Foxp3, and IL-33 signaling. VAT macrophages and DCs are the major antigen-presenting cells that express MHC-II to activate and increase VAT-Treg cells. In VAT, white adipose tissue produces IL-33 to increase VAT-Treg cell generation. Leptin produced by adipose cells inhibits VAT-Treg cell proliferation and induces anergy. Leptin-neutralizing antibody reverses anergy and increases mTOR activation and Treg cell proliferation. VAT-Treg cells have high expression of enzyme hydroxyprostaglandin dehydrogenase (HPGD), which is dependent on PPAR $\gamma$. HPGD produces 15-keto PGE 2 to suppress conventional T cell activation and proliferation. Intestinal Treg cells mainly contain Gata3 ${ }^{+}$tTreg, $\mathrm{ROR} \gamma \mathrm{t}^{+}$, and ROR $\gamma \mathrm{t}^{-}$pTreg cells. ROR $\gamma \mathrm{t}^{+}$pTreg cells are the dominant population in the colon, while ROR $\gamma \mathrm{t}^{-}$pTreg cells mainly localize in small intestine. Their difference is mainly derived from the dominant effect of microbiota and dietary metabolites, respectively, in the colon and small intestine. In the colon, metabolism of tryptophan produces AhR ligands, such as kynurenine, to selectively enhance the generation of Foxp3 ${ }^{+}$Treg cells. In the small intestine, dietary vitamin $A$ is present at high concentrations. RA, a metabolite from vitamin $A$, induces pTreg cells from naïve $T$ cells in the small intestine in combination with TGF- $\beta$. RA also induces the expression of CCR9 on the surface of Treg cells to facilitate their migration to the small intestine. In tumor tissue, Treg cells not only display eTreg cell phenotypes similar to non-lymphoid organs but also express some tumor-specific gene signatures. Compared to conventional T cells, Treg cells have a metabolic advantage in tumor microenvironment, which has low glucose/amino acid, high lactate/hypoxia, and elevated oxidative stress. Genetic or pharmacological perturbation of metabolic pathway PI3K/AKt/Foxo signaling directly impacts tumor-resident Treg cell homeostasis, function and anti-tumor immunotherapy. VAT, visceral adipose tissue; AhR, aryl hydrocarbon receptor.

Recently, using a $\mathrm{T}$ cell receptor transgenic mouse line in which VAT-Treg cells are enriched, the Mathis group identified a two-step, two-site developmental axis for VAT Treg cells (159). Single cell RNA-sequencing (scRNA-seq) and assay for transposase-accessible chromatin sequencing (ATACseq) analyses reveal that splenic Treg cells that are destined to become VAT-Treg are primed within the secondary lymphoid organs, where they are defined by low expression of PPAR $\gamma$ that allows them to upregulate selective VAT-Treg-associated transcriptional programs. These PPAR $\gamma^{\text {lo }}$ Treg cells then migrate to the VAT, where they are educated and exposed to local microenvironmental cues to differentiate into VAT-Treg cells. The accumulation of VAT-Treg cells is dependent upon TCR, Foxp3, and IL-33 signaling, and is associated with substantial epigenetic remodeling. Specifically, the critical role of IL-33 in the development and maintenance of VAT-Treg cells is dependent upon the high expression of IL-33 receptor ST2 (160). IL-33 treatment leads to reduced obesity, improved glucose tolerance, and increased proportion of ST2 ${ }^{+}$Treg cells in the VAT of genetically obese diabetic mice (161). White adipose tissue is the main source of IL-33 in VAT (162), and $\gamma \delta$ T cells may also promote IL-33 production by VAT, as mice lacking $\gamma \delta \mathrm{T}$ cells exhibit decreases of ST2 ${ }^{+}$Treg cells in VAT (163). Subsequent studies also demonstrate that IL-33 is a critical driver for the differentiation and function of other tissue-resident Treg cells, including in the brain (164) and intestine (165). Moreover, TCR: MHC-II interactions are also required for the development and maintenance of VAT-Treg cells (166). In MHC-II-deficient mice, VAT-Treg cell number is greatly reduced, associated with less expression of Gata3 (160). Among the antigen-presenting cells that express MHC-II, VAT macrophages (167) and DCs (160) have been reported to activate and increase VAT-Treg cells. These results together demonstrate that the ligand-receptor interactions between cells in the adipose tissues instruct plasticity in the VAT and generate unique VAT-Treg cells. However, questions regarding the phenotype and function of VAT-Treg cells in humans and how to manipulate VAT-Treg cells to prevent obesity and related metabolic diseases still remain to be addressed.

\section{Intestine}

The intestine is constituted by small intestine and large intestine, with the latter containing cecum and colon. Due to the direct exposure to exogenous dietary antigens, the intestine must both protect the host from harmful pathogens and maintain tolerance to intestinal microbiota and beneficial metabolites. This sophisticated task requires a close collaboration within the intestinal network to recognize and distinguish the harmful and beneficial material from the diet. The intestinal wall contains four major layers: mucosa, submucosa, muscularis, and serosa (168). The epithelial cells of the mucosa form the first physical barrier and are supported by an underlying network of immune cells in the lamina propria, local lymphoid structure like Peyer's patches (PPs) and the draining lymph nodes. Treg cells play a critical role in suppressing local inflammatory responses and maintaining intestinal homeostasis (169). To adapt to the highly specific environment, Treg cells develop tissue-specific heterogeneity. Indeed, a substantial proportion of Helios ${ }^{-}$neuropilin- $1^{-}$pTreg cells are found in the small intestine and colon, as well as Helios ${ }^{+}$neuropilin- $1^{+}$tTreg cells that express Gata3 (170). Thus, the intestine represents a unique mucosal site that requires both tTreg and pTreg cells for homeostasis.

The cues that allow for pTreg cell induction in the intestine have been extensively studied. Due to the similar differentiation requirements and expression of ROR $\gamma \mathrm{t}, \mathrm{ROR} \gamma \mathrm{t}^{+}$Foxp $3^{+}$Treg cells were once thought to be precursors for unstable Treg cells that would differentiate into Th17 cells $(171,172)$. However, a large population of $\mathrm{ROR}_{\gamma} \mathrm{t}^{+}$pTreg cells are present in the 
colon under steady state $(170,173,174)$, while the small intestine mainly contains ROR $\gamma \mathrm{t}^{-}$pTreg cells (175). Transcriptomic analysis has revealed that the signature of ROR $\gamma \mathrm{t}^{+} \mathrm{Foxp} 3^{+}$Treg cells is similar to both Treg and Th17 cells, but has a higher overlap with Treg cells (174). Further, ROR $\gamma \mathrm{t}^{+}$Foxp $3^{+}$Treg cells display significantly demethylation at Treg cell-specific signature genes like Foxp3, Ctla4, and Tnfrsf18, indicating that they are a lineage-stable population with potent suppressive activity (174). TCR repertoire analysis further reveals that the ROR $\gamma \mathrm{t}^{+} \mathrm{Foxp}^{+}$population is distinct from other colonic $\mathrm{T}$ cell subsets (176). The development of ROR $\gamma \mathrm{t}^{+}$Foxp $3^{+}$cells in the mucosa can be derived from naive $\mathrm{CD} 4^{+} \mathrm{T}$ cells in the periphery and pass through a $\mathrm{ROR} \gamma \mathrm{t}^{-}$Treg intermediate before co-expressing ROR $\gamma \mathrm{t}(176)$. CX3CR1 ${ }^{+}$antigen-presenting cells may provide specific signals for the development of ROR $\gamma^{+}$ Treg cells (176). Moreover, loss of ROR $\gamma \mathrm{t}^{+} \mathrm{Foxp}^{+}$Treg cells exaggerates several models of mucosal autoimmunity, indicating that this subpopulation is functionally important $(170,173,174)$. Thus, co-expression of ROR $\gamma \mathrm{t}$ and Foxp3 is also essential for establishing Treg cell function in the intestine.

The intestinal microenvironment differs in the colon and small intestine. The colon harbors multiple species of microbiota to facilitate the development of ROR $\gamma \mathrm{t}^{+}$Treg cells $(170,173)$. Germ-free mice treated with antibiotics greatly diminish the abundance of colonic pTreg cells, leaving a predominant Helios ${ }^{+}$ tTreg cell population $(173,177,178)$. The abundance of ROR $\gamma \mathrm{t}^{+}$ Treg cells is linked to changes in the microbiota, whereas ROR $\gamma \mathrm{t}^{-}$Treg cells are relatively insensitive $(170,173,175$, 179). Many microbial species such as Clostridium ramosum, Staphylococcus saprophyticus, Bacteroides thetaiotaomicron, and Clostridium histolyticum, have the potential to induce pTreg cell generation (170, 173, 180-183). In addition, Helicobacter hepaticus-reactive naïve $\mathrm{CD} 4^{+} \mathrm{T}$ cells differentiate into $\mathrm{ROR} \gamma \mathrm{t}^{+}$ Treg cells upon $H$. hepaticus colonization, which is dependent upon the transcription factor c-Maf (183). The ROR $\gamma \mathrm{t}^{+}$Treg cell differentiation is also dependent upon constant antigen exposure, as mice deficient in MHC-II have greatly fewer ROR $\gamma \mathrm{t}^{+}$Treg cells (170). The aryl hydrocarbon receptor (AhR) is a sensor that detects environmental pollutants and physiological compounds from diet, host cells, and microbiota (184). Microbiota, such as Lactobacillus species, metabolize tryptophan to generate AhR ligands (185). Metabolism of tryptophan produces a series of AhR ligands, such as kynurenine, to selectively enhance the generation of Foxp $3^{+}$Treg cells in vitro (186). Intriguingly, the microbiota-induced ROR $\gamma \mathrm{t}^{+}$Treg cells express the highest amount of AhR compared to various organs (179). Treg cellspecific deletion of AhR impairs pTreg, but not tTreg, cell homeostasis in the colon (179). Moreover, AhR-expressing Treg cells have enhanced in vivo suppressive activity compared with Treg cells lacking AhR expression in a $\mathrm{T}$ cell transfer model of colitis, highlighting a central role of AhR in microbiotainduced pTreg cell generation and function (179). Microbiota also increase the expression of GPR15, an orphan G-protein coupled receptor, to promote the specific homing of Treg cells to the large intestine (187). Therefore, microbiota promote the generation, function, and influx of Treg cells in the large intestine.
Studies comparing changes in dietary composition and germfree mice indicate that the induction of Treg cells in the small intestine is mainly dependent upon dietary antigens rather than microbiota, and diet-generated Treg cells are mostly pTreg cells $(175,182,188)$. For example, all-trans RA acts in concert with TGF- $\beta$ for $p$ Treg cell generation in the small intestine $(53,189$, 190), where dietary vitamin A is abundant (191) and is converted to RA with the help of local epithelial cells and DCs (192). Moreover, RA induces the expression of CCR9 on Treg cells, which is required for their migration to small intestine $(53,189)$. RA-induced pTreg cell generation underlies oral tolerance, as mice treated with a vitamin A-deficient diet display defective in the induction of oral tolerance (193). Recent studies have also indicated a critical role for isoleucine in regulating Treg cell homeostasis in the small intestine (194). Other dietary mechanisms controlling the homeostasis of small intestinal Treg cells in vivo require further investigation.

\section{Tumor Tissue}

Tumor tissues are complex environments that contains tumor cells, stromal cells, and infiltrating immune cells (195-197). Due to the malignant cell proliferation, tumor cells require sufficient energy supply and exert metabolic effects on local tumor microenvironment (198). A large population of Treg cells exist in the tumor microenvironment and present a major obstacle for effective anti-tumor therapy $(195,196)$. Treg cells isolated from tumors are often in an activated state with a metabolic signature that is distinct from lymphoid tissue Treg cells. Their transcriptome shares high similarities with "tissue Treg cells" residing in non-lymphoid tissues (199). Recent studies have identified an important role of Foxo1 in regulating eTreg cells in tumor (200). Hyperactivation of Foxo1 preferentially depletes eTreg cells, which enhances $\mathrm{CD} 8^{+} \mathrm{T}$ cell function and antitumor immunity (200), suggesting that targeting PI3K/Akt/Foxo pathway in Treg cells could possibly break the Treg cell barrier in anti-tumor therapy. Inactivation of PI3K p110 in Treg cells also unleashes cytotoxic $\mathrm{CD} 8^{+} \mathrm{T}$ cells and induces tumor regression and better survival (201-203). These data reveal that subtle perturbations in metabolic signaling could impact tumor-resident Treg cell homeostasis and function. Despite the similarities with Treg cells in non-lymphoid organs, tumorresident Treg cells also highly express unique signatures, such as Ccr8, Tnfrsf8, Cxcr3, and Samsn1 $(199,204)$, which might serve as valuable targets for tumor immunotherapy.

Tumor cells modulate several environmental cues to affect tumor-resident Treg cell generation and function, in which the competition of extracellular nutrients stands out. Cancer cells undergo a transition of OXPHOS to aerobic glycolysis, known as the Warburg effect (198). This metabolic shift in cancer cells leads to the consumption of environmental glucose and glutamine, thus leading local $\mathrm{T}$ cells to adopt unresponsive or functionally exhausted states $(205,206)$. In contrast, glucose deprivation can drive Foxp3 expression, shifting $\mathrm{T}$ cell differentiation from conventional T cells toward iTreg cells $(16,78,207)$. Likewise, tumor cells also compete with $\mathrm{T}$ cells for extracellular amino acids for metabolism. Amino acids, especially glutamine and leucine, are required to fuel mTORC1 activation in conventional 
$\mathrm{T}$ cells, promoting $\mathrm{T}$ cell differentiation toward Th1, Th2, and Th17 cells, but have a less effect on iTreg cells (208). Deletion of amino acid transporters ASCT2 and SLC7a5 (LAT1) leads to normal Treg cell differentiation (209, 210). Moreover, a decrease of intracellular $\alpha \mathrm{KG}$, caused by the limited availability of extracellular glutamine, also promotes the generation of iTreg cells rather than Th1 cells (211). Interestingly, Treg cells could further deplete environmental amino acid levels by inducing amino acid-consuming enzymes in DCs, such as arginase 1, histidine decarboxylase, or threonine dehydrogenase, through TGF- $\beta$ and IL-10 secretion. Enzymatic consumption of amino acids by DCs could further inhibit mTORC1 activation, thus synergizing with TGF- $\beta$ for Treg cell induction (212). These results indicate that nutrient availability in the tumor microenvironment can suppress $\mathrm{T}$ cell responses, in part, through induction of Treg cells.

Apart from glucose and amino acids, tumor cells also perturb environmental fatty acid concentrations. In some cancer cells, the extracellular liberation of free fatty acids from more complex lipid species is increased (198). However, the exact regulation of fatty acid availability and diversity in the tumor microenvironment remains elusive and debatable. Mouse iTreg cells are reported to preferentially use FAO (16), and short chain fatty acids can promote iTreg cell differentiation $(88,213)$. In brain tumors, higher percentages of Treg cells that express CD36 and SLC27A1 (fatty acid transporters) are found (83). Inhibition of lipid uptake with sulfo-N-succinimidyl oleate (SSO) or FAO with etomoxir (Eto) prevents Treg cell immunosuppressive capabilities in this environment (83). Therefore, future studies could analyze if Cptla deficiency affects specific tumor Treg cell responses (91). Under steady state, Treg cells rely on mTORC1mediated lipogenesis for their expansion and function (22), and proliferating Treg cells in the MC38 tumor microenvironment also rely on de novo fatty acid synthesis to accumulate intracellular lipids and complement glycolysis for Treg cell expansion (214). Therefore, whether nutrient competitiveness influences and whether fatty acids are preferentially catabolized or synthesized to support Treg cell accumulation or function in tumors await detailed investigation.

Metabolic factors other than nutrients also contribute to heightened Treg cell accumulation and function in the tumor microenvironment. Hypoxia is common in some regions of tumor tissue due to lack of vascularity (215). HIF-1 $\alpha$ is usually upregulated upon hypoxia, and is positively correlated with the malignancy of certain tumors (216). Previous studies have identified HIF- $1 \alpha$ as a negative regulator of iTreg cell differentiation, while it promotes Th17 cell differentiation $(78,217)$. However, HIF- $1 \alpha$ is required for optimal Treg cell suppressive activity in vivo (218). A study using mice with Treg cell-specific deletion of HIF-1 $\alpha$ has revealed that, under hypoxia in a mouse model of glioma, HIF- $1 \alpha$ directs glucose away from the mitochondria, leaving Treg cells dependent on fatty acids for mitochondrial metabolism (83). This mechanism provides an advantage for Treg cells to thrive in low-glucose tumor microenvironment. The tumor microenvironment also accumulates excess lactate produced by tumor cells due to their high rates of glycolysis (198). A major consequence of lactate secretion is microenvironmental acidification (198). Multiple studies have identified a deleterious role of lactate in inhibiting $\mathrm{CD}^{+} \mathrm{T}$ cell-mediated anti-tumor immunity, while neutralization of acidosis improves checkpoint blockade (219-221). In contrast, Treg cell suppressive function and proliferation are unaffected by the addition of lactate due to reduced glycolysis (17). Mechanistically, conventional effector $\mathrm{T}$ cells balance $\mathrm{NAD}^{+} / \mathrm{NADH}$ ratios through conversion of pyruvate into lactate to maintain glycolysis $(17,138)$, whereas Treg cells do not require high rates of glycolysis and can thus balance $\mathrm{NAD}^{+} / \mathrm{NADH}$ through oxidation of exogenous lactate (17). As a result, loss of glycolysis is detrimental to conventional effector $\mathrm{T}$ cells but not Treg cells (16), providing Treg cells with a metabolic advantage in response to low-glucose and high-lactate tumor microenvironment (17). Furthermore, oxidative stress is an additional metabolic feature in the tumor microenvironment (198). Treg cells are relatively more sensitive to oxidative stress than conventional $\mathrm{T}$ cells and undergo potent apoptosis in the tumor microenvironment (222). Intriguingly, apoptotic Treg cells have been revealed to mediate superior immunosuppression through converting a large amount of ATP to adenosine via CD39 and CD73 (222), suggesting that tumorresident Treg cells sustain and amplify suppressive activity by inadvertent death via oxidative stress. These observations all underscore the importance of metabolic adaption of Treg cells in tumor microenvironment for their suppressive activity, although the precise metabolic status of tumor Treg cells needs to be determined, such as by single cell metabolomics (151) or computational-based inference of metabolic gene expression in scRNA-seq data (223).

\section{CONCLUDING REMARKS AND FUTURE PERSPECTIVES}

Current studies illustrate that environmental and intracellular metabolic factors orchestrate Treg cell stability, plasticity, and tissue-specific heterogeneity in different contexts. How Treg cells metabolically adapt to different environmental contexts in vivo still remains underexplored. From the perspective of intricate molecular network, mTOR likely acts as a "metabolic hub" that senses and adjusts the cellular metabolic state, thereby balancing the catabolism and anabolism in Treg cells to define their functional and phenotypic state. Therefore, dissecting the upstream metabolic inputs to mTOR in Treg cells remains a key future direction and may uncover how environmental cues are transmitted to Treg cells for functional reprogramming. Apart from mTOR, the roles of other metabolic components, such as mitochondrial respiratory chain complexes, are being uncovered in Treg cells. It will be intriguing to determine whether the loss of various metabolic components within Treg cells causes distinct pathologies in mice. Utilizing CRISPR (Clustered Regularly Interspaced Short Palindromic Repeats) screening, novel metabolic regulators in Treg cell stability, plasticity and tissue-specific heterogeneity may be discovered, to further expand our view on Treg cell-specific metabolic regulation. 
Unlike Treg cell instability, few studies have discussed the role of metabolism for Th-like Treg cell generation. The transcriptional landscape could be altered in Th-like Treg cells to allow the co-expression of Th transcription factors and inflammatory cytokines, along with Foxp3 expression, which may involve epigenetic regulation, such as histone acetylation. Metabolites such as acetyl-CoA can directly alter the activity of chromatin-modifying enzymes, including histone acetyl-transferases (HATs), histone methyl-transferases (HMTs) and sirtuins. It will be interesting to uncover the metabolic pathways and their key drivers that orchestrate the epigenetic landscape of the Th transcription factors and inflammatory cytokines in Thlike Treg cells. The development of ATAC-seq has allowed analysis of transcription factor occupancy in specific cell types, which provides a starting point for studying the interplay between metabolism and epigenetics in shaping Treg cell plasticity (224).

Technological advances, such as scRNA-seq, are likely to uncover how Treg cells metabolically adapt to different environments. For instance, a recent scRNA-seq analysis of colonic and skin Treg cells revealed that Treg cells undergo metabolic reprogramming as they migrate from lymphoid organ to non-lymphoid barrier organs (225). Specifically, Treg cells convert from expressing glycolysis- and migration-associated genes toward expressing genes associated with fatty-acid metabolism and cytokine production. Intriguingly, lymphoid organs are glucose-rich relative to non-lymphoid organs or tumor microenvironment (169), while non-lymphoid organs may express higher levels of fatty acids. These differences in local nutrient composition likely explain why Treg cells from adipose tissue and intestine express higher levels of the fatty acid-binding transporters than those in lymphoid tissues. The interplay between local nutrient composition and Treg cell

\section{REFERENCES}

1. Ohkura N, Kitagawa Y, Sakaguchi S. Development and maintenance of regulatory $\mathrm{T}$ cells. Immunity. (2013) 38:414-23. doi: 10.1016/j.immuni.2013.03.002

2. Josefowicz SZ, Lu LF, Rudensky AY. Regulatory T cells: mechanisms of differentiation and function. Annu Rev Immunol. (2012) 30:531-64. doi: 10.1146/annurev.immunol.25.022106.141623

3. Malek TR, Castro I. Interleukin-2 receptor signaling: at the interface between tolerance and immunity. Immunity. (2010) 33:153-65. doi: 10.1016/j.immuni.2010.08.004

4. Chinen T, Kannan AK, Levine AG, Fan X, Klein U, Zheng Y, et al. An essential role for the IL-2 receptor in Treg cell function. Nat Immunol. (2016) 17:1322-33. doi: 10.1038/ni.3540

5. Shi H, Liu C, Tan H, Li Y, Nguyen TM, Dhungana Y, et al. Hippo kinases Mst1 and Mst2 sense and amplify IL-2R-STAT5 signaling in regulatory T cells to establish stable regulatory activity. Immunity. (2018) 49:899-914.e6. doi: 10.1016/j.immuni.2018.10.010

6. Shevach EM, Thornton AM. tTregs, pTregs, and iTregs: similarities and differences. Immunol Rev. (2014) 259:88-102. doi: 10.1111/imr.12160

7. Josefowicz SZ, Rudensky A. Control of regulatory $\mathrm{T}$ cell lineage commitment and maintenance. Immunity. (2009) 30:616-25. doi: 10.1016/j.immuni.2009.04.009 stability, plasticity, and tissue-specific heterogeneity also likely accounts for the unique physiological functions of Treg cells in non-lymphoid organs, such as controlling adipose tissue homeostasis (226). As scRNA-seq, ATAC-seq, in situ imaging, and metabolic profiling have greatly expanded the possible view of cell-cell communication $(227,228)$, it may be possible to use these technologies to discover novel ligand-receptor pairs or signaling pathways responsible for Treg cell stability and plasticity in these sites. Recent work has also established that Treg cells from hypoxic tumors express higher fatty acid transporters and catabolize free fatty acids for immunosuppression (83). Thus, understanding the detailed mechanisms of metabolic crosstalk between Treg cells and tumor cells may uncover essential regulatory networks in tumorigenesis, tumor progression, and therapy resistance. Therefore, analysis of Treg cellmetabolic interactions may provide new opportunities to develop novel Treg cell-based immune-metabolic interventions for the treatment of inflammatory diseases and tumor progression.

\section{AUTHOR CONTRIBUTIONS}

All authors listed have made a substantial, direct and intellectual contribution to the work, and approved it for publication.

\section{FUNDING}

This work was supported by NIH AI105887, AI131703, AI140761, AI150241, AI150514, CA221290, and NS64599 (to HC).

\section{ACKNOWLEDGMENTS}

The authors acknowledge Y. Wang and N. Chapman for editing the manuscript.
8. Hsieh CS, Lee HM, Lio CW. Selection of regulatory T cells in the thymus. Nat Rev Immunol. (2012) 12:157-67. doi: 10.1038/nri3155

9. Chen W, Jin W, Hardegen N, Lei KJ, Li L, Marinos N, et al. Conversion of peripheral $\mathrm{CD} 4+\mathrm{CD} 25-$ naive $\mathrm{T}$ cells to $\mathrm{CD} 4+\mathrm{CD} 25+$ regulatory $\mathrm{T}$ cells by TGF-beta induction of transcription factor Foxp3. J Exp Med. (2003) 198:1875-86. doi: 10.1084/jem.20030152

10. Yadav M, Stephan S, Bluestone JA. Peripherally induced tregs - role in immune homeostasis and autoimmunity. Front Immunol. (2013) 4:232. doi: 10.3389/fimmu.2013.00232

11. Thornton AM, Korty PE, Tran DQ, Wohlfert EA, Murray PE, Belkaid Y, et al. Expression of Helios, an Ikaros transcription factor family member, differentiates thymic-derived from peripherally induced Foxp3+ T regulatory cells. J Immunol. (2010) 184:3433-41. doi: 10.4049/jimmunol.0904028

12. Yadav M, Louvet C, Davini D, Gardner JM, Martinez-Llordella M, Bailey-Bucktrout S, et al. Neuropilin-1 distinguishes natural and inducible regulatory $\mathrm{T}$ cells among regulatory $\mathrm{T}$ cell subsets in vivo. J Exp Med. (2012) 209:1713-22, S1-19. doi: 10.1084/jem.20 120822

13. Weiss JM, Bilate AM, Gobert M, Ding Y, Curotto de Lafaille MA, Parkhurst $\mathrm{CN}$, et al. Neuropilin 1 is expressed on thymus-derived natural regulatory $\mathrm{T}$ cells, but not mucosa-generated induced Foxp3+ T reg cells. J Exp Med. (2012) 209:1723-42, S1. doi: 10.1084/jem.20120914 
14. Wang A, Luan HH, Medzhitov R. An evolutionary perspective on immunometabolism. Science. (2019) 363:eaar3932. doi: $10.1126 /$ science.aar3932

15. O’Neill LA, Kishton RJ, Rathmell J. A guide to immunometabolism for immunologists. Nat Rev Immunol. (2016) 16:553-65. doi: $10.1038 /$ nri.2016.70

16. Michalek RD, Gerriets VA, Jacobs SR, Macintyre AN, MacIver NJ, Mason EF, et al. Cutting edge: distinct glycolytic and lipid oxidative metabolic programs are essential for effector and regulatory CD4+ T cell subsets. J Immunol. (2011) 186:3299-303. doi: 10.4049/jimmunol.1003613

17. Angelin A, Gil-de-Gomez L, Dahiya S, Jiao J, Guo L, Levine $\mathrm{MH}$, et al. Foxp3 reprograms $\mathrm{T}$ cell metabolism to function in lowglucose, high-lactate environments. Cell Metab. (2017) 25:1282-93.e7. doi: 10.1016/j.cmet.2016.12.018

18. Gerriets VA, Kishton RJ, Johnson MO, Cohen S, Siska PJ, Nichols AG, et al. Foxp3 and Toll-like receptor signaling balance Treg cell anabolic metabolism for suppression. Nat Immunol. (2016) 17:1459-66. doi: 10.1038/ni.3577

19. Howie D, Cobbold SP, Adams E, Ten Bokum A, Necula AS, Zhang W, et al. Foxp3 drives oxidative phosphorylation and protection from lipotoxicity. JCI Insight. (2017) 2:e89160. doi: 10.1172/jci.insight.89160

20. Newton R, Priyadharshini B, Turka LA. Immunometabolism of regulatory T cells. Nat Immunol. (2016) 17:618-25. doi: 10.1038/ni.3466

21. Galgani M, De Rosa V, La Cava A, Matarese G. Role of metabolism in the immunobiology of regulatory T cells. J Immunol. (2016) 197:2567-75. doi: 10.4049/jimmunol.1600242

22. Zeng H, Yang K, Cloer C, Neale G, Vogel P, Chi H. mTORC1 couples immune signals and metabolic programming to establish T(reg)-cell function. Nature. (2013) 499:485-90. doi: 10.1038/nature12297

23. Zeng $\mathrm{H}$, Chi H. Metabolic control of regulatory $\mathrm{T}$ cell development and function. Trends Immunol. (2015) 36:3-12. doi: 10.1016/j.it.2014.08.003

24. Shi H, Chapman NM, Wen J, Guy C, Long L, Dhungana Y, et al. Amino acids license kinase mTORC1 activity and Treg cell function via small G proteins Rag and Rheb. Immunity. (inpress) doi: 10.1016/j.immuni.2019.10.001

25. Wei J, Long L, Yang K, Guy C, Shrestha S, Chen Z, et al. Autophagy enforces functional integrity of regulatory $\mathrm{T}$ cells by coupling environmental cues and metabolic homeostasis. Nat Immunol. (2016) 17:277-85. doi: $10.1038 /$ ni.3365

26. Shrestha S, Yang K, Guy C, Vogel P, Neale G, Chi H. Treg cells require the phosphatase PTEN to restrain TH1 and TFH cell responses. Nat Immunol. (2015) 16:178-87. doi: 10.1038/ni.3076

27. Huynh A, DuPage M, Priyadharshini B, Sage PT, Quiros J, Borges CM, et al. Control of PI(3) kinase in Treg cells maintains homeostasis and lineage stability. Nat Immunol. (2015) 16:188-96. doi: 10.1038/ni.3077

28. Bennett CL, Christie J, Ramsdell F, Brunkow ME, Ferguson PJ, Whitesell $\mathrm{L}$, et al. The immune dysregulation, polyendocrinopathy, enteropathy, Xlinked syndrome (IPEX) is caused by mutations of FOXP3. Nat Genet. (2001) 27:20-1. doi: $10.1038 / 83713$

29. Brunkow ME, Jeffery EW, Hjerrild KA, Paeper B, Clark LB, Yasayko SA, et al. Disruption of a new forkhead/winged-helix protein, scurfin, results in the fatal lymphoproliferative disorder of the scurfy mouse. Nat Genet. (2001) 27:68-73. doi: 10.1038/83784

30. Komatsu N, Mariotti-Ferrandiz ME, Wang Y, Malissen B, Waldmann H, Hori S. Heterogeneity of natural Foxp3+ T cells: a committed regulatory Tcell lineage and an uncommitted minor population retaining plasticity. Proc Natl Acad Sci USA. (2009) 106:1903-8. doi: 10.1073/pnas.0811556106

31. Rubtsov YP, Niec RE, Josefowicz S, Li L, Darce J, Mathis D, et al. Stability of the regulatory $\mathrm{T}$ cell lineage in vivo. Science. (2010) 329:1667-71. doi: 10.1126/science.1191996

32. Overacre AE, Vignali DAA. T-reg stability: to be or not to be. Curr Opin Immunol. (2016) 39:39-43. doi: 10.1016/j.coi.2015.12.009

33. Hori S. Lineage stability and phenotypic plasticity of Foxp3(+) regulatory $\mathrm{T}$ cells. Immunol Rev. (2014) 259:159-72. doi: 10.1111/imr.12175

34. Sakaguchi S, Vignali DA, Rudensky AY, Niec RE, Waldmann H. The plasticity and stability of regulatory T cells. Nat Rev Immunol. (2013) 13:4617. doi: $10.1038 /$ nri3464

35. Feng Y, Arvey A, Chinen T, van der Veeken J, Gasteiger G, Rudensky AY. Control of the inheritance of regulatory $\mathrm{T}$ cell identity by a cis element in the Foxp3 locus. Cell. (2014) 158:749-63. doi: 10.1016/j.cell.2014.07.031
36. Kastner L, Dwyer D, Qin FX. Synergistic effect of IL-6 and IL-4 in driving fate revision of natural Foxp3+ regulatory T cells. J Immunol. (2010) 185:577886. doi: 10.4049/jimmunol.0901948

37. Zhou X, Bailey-Bucktrout SL, Jeker LT, Penaranda C, Martinez-Llordella $\mathrm{M}$, Ashby $\mathrm{M}$, et al. Instability of the transcription factor Foxp3 leads to the generation of pathogenic memory T cells in vivo. Nat Immunol. (2009) 10:1000-7. doi: 10.1038/ni.1774

38. Duarte JH, Zelenay S, Bergman ML, Martins AC, Demengeot J. Natural Treg cells spontaneously differentiate into pathogenic helper cells in lymphopenic conditions. Eur J Immunol. (2009) 39:948-55. doi: 10.1002/eji.200839196

39. Miyao T, Floess S, Setoguchi R, Luche H, Fehling HJ, Waldmann H, et al. Plasticity of Foxp3(+) T cells reflects promiscuous Foxp3 expression in conventional T cells but not reprogramming of regulatory T cells. Immunity. (2012) 36:262-75. doi: 10.1016/j.immuni.2011.12.012

40. Okada M, Hibino S, Someya K, Yoshmura A. Regulation of regulatory T cells: epigenetics and plasticity. Adv Immunol. (2014) 124:249-73. doi: 10.1016/B978-0-12-800147-9.00008-X

41. Li X, Zheng Y. Regulatory T cell identity: formation and maintenance. Trends Immunol. (2015) 36:344-53. doi: 10.1016/j.it.2015.04.006

42. Barbi J, Pardoll D, Pan F. Treg functional stability and its responsiveness to the microenvironment. Immunol Rev. (2014) 259:115-39. doi: $10.1111 /$ imr. 12172

43. Xu L, Kitani A, Stuelten C, McGrady G, Fuss I, Strober W. Positive and negative transcriptional regulation of the Foxp3 gene is mediated by access and binding of the Smad3 protein to enhancer I. Immunity. (2010) 33:31325. doi: 10.1016/j.immuni.2010.09.001

44. Li X, Liang Y, LeBlanc M, Benner C, Zheng Y. Function of a Foxp3 ciselement in protecting regulatory $\mathrm{T}$ cell identity. Cell. (2014) 158:734-48. doi: 10.1016/j.cell.2014.07.030

45. Rudra D, Egawa T, Chong MM, Treuting P, Littman DR, Rudensky AY. Runx-CBFbeta complexes control expression of the transcription factor Foxp3 in regulatory $T$ cells. Nat Immunol. (2009) 10:1170-7. doi: 10.1038/ni.1795

46. Kim HP, Leonard WJ. CREB/ATF-dependent T cell receptor-induced FoxP3 gene expression: a role for DNA methylation. J Exp Med. (2007) 204:1543-51. doi: 10.1084/jem.20070109

47. Long M, Park SG, Strickland I, Hayden MS, Ghosh S. Nuclear factorkappaB modulates regulatory $\mathrm{T}$ cell development by directly regulating expression of Foxp3 transcription factor. Immunity. (2009) 31:921-31. doi: 10.1016/j.immuni.2009.09.022

48. Floess S, Freyer J, Siewert C, Baron U, Olek S, Polansky J, et al. Epigenetic control of the foxp3 locus in regulatory T cells. PLoS Biol. (2007) 5:e38. doi: 10.1371/journal.pbio.0050038

49. Sawant DV, Vignali DA. Once a Treg, always a Treg? Immunol Rev. (2014) 259:173-91. doi: 10.1111/imr.12173

50. Kitagawa Y, Ohkura N, Sakaguchi S. Molecular determinants of regulatory T cell development: the essential roles of epigenetic changes. Front Immunol. (2013) 4:106. doi: 10.3389/fimmu.2013.00106

51. Polansky JK, Schreiber L, Thelemann C, Ludwig L, Kruger M, Baumgrass $\mathrm{R}$, et al. Methylation matters: binding of Ets-1 to the demethylated Foxp3 gene contributes to the stabilization of Foxp3 expression in regulatory T cells. J Mol Med. (2010) 88:1029-40. doi: 10.1007/s00109-0100642-1

52. Zheng Y, Josefowicz S, Chaudhry A, Peng XP, Forbush K, Rudensky AY. Role of conserved non-coding DNA elements in the Foxp3 gene in regulatory T-cell fate. Nature. (2010) 463:808-12. doi: 10.1038/nature08750

53. Mucida D, Park Y, Kim G, Turovskaya O, Scott I, Kronenberg M, et al. Reciprocal TH17 and regulatory $\mathrm{T}$ cell differentiation mediated by retinoic acid. Science. (2007) 317:256-60. doi: 10.1126/science.1145697

54. Xiao S, Jin H, Korn T, Liu SM, Oukka M, Lim B, et al. Retinoic acid increases Foxp3+ regulatory $\mathrm{T}$ cells and inhibits development of Th17 cells by enhancing TGF-beta-driven Smad3 signaling and inhibiting IL-6 and IL-23 receptor expression. J Immunol. (2008) 181:2277-84. doi: 10.4049/jimmunol.181.4.2277

55. Lu L, Lan Q, Li Z, Zhou X, Gu J, Li Q, et al. Critical role of alltrans retinoic acid in stabilizing human natural regulatory $\mathrm{T}$ cells under inflammatory conditions. Proc Natl Acad Sci USA. (2014) 111:E3432-40. doi: $10.1073 /$ pnas. 1408780111 
56. Lu L, Ma J, Li Z, Lan Q, Chen M, Liu Y, et al. All-trans retinoic acid promotes TGF-beta-induced Tregs via histone modification but not DNA demethylation on Foxp3 gene locus. PLoS ONE. (2011) 6:e24590. doi: 10.1371/journal.pone.0024590

57. Hill JA, Hall JA, Sun CM, Cai Q, Ghyselinck N, Chambon P, et al. Retinoic acid enhances Foxp3 induction indirectly by relieving inhibition from CD4+CD44hi Cells. Immunity. (2008) 29:758-70. doi: 10.1016/j.immuni.2008.09.018

58. Yue X, Trifari S, Aijo T, Tsagaratou A, Pastor WA, Zepeda-Martinez JA, et al. Control of Foxp3 stability through modulation of TET activity. J Exp Med. (2016) 213:377-97. doi: 10.1084/jem.20151438

59. Sasidharan Nair V, Song MH, Oh KI. Vitamin C Facilitates demethylation of the Foxp3 enhancer in a Tet-dependent manner. J Immunol. (2016) 196:2119-31. doi: 10.4049/jimmunol.1502352

60. Baron U, Floess S, Wieczorek G, Baumann K, Grutzkau A, Dong J, et al. DNA demethylation in the human FOXP3 locus discriminates regulatory $\mathrm{T}$ cells from activated FOXP3(+) conventional T cells. Eur J Immunol. (2007) 37:2378-89. doi: 10.1002/eji.200737594

61. Yue X, Lio CJ, Samaniego-Castruita D, Li X, Rao A. Loss of TET2 and TET3 in regulatory T cells unleashes effector function. Nat Commun. (2019) 10:2011. doi: 10.1038/s41467-019-09541-y

62. Nakatsukasa H, Oda M, Yin J, Chikuma S, Ito M, Koga-Iizuka M, et al. Loss of TET proteins in regulatory $\mathrm{T}$ cells promotes abnormal proliferation, Foxp3 destabilization and IL-17 expression. Int Immunol. (2019) 31:335-47. doi: 10.1093/intimm/dxz008

63. Joshi S, Pantalena LC, Liu XK, Gaffen SL, Liu H, Rohowsky-Kochan C, et al. 1,25-dihydroxyvitamin $\mathrm{D}(3)$ ameliorates Th17 autoimmunity via transcriptional modulation of interleukin-17A. Mol Cell Biol. (2011) 31:3653-69. doi: 10.1128/MCB.05020-11

64. Jeffery LE, Burke F, Mura M, Zheng Y, Qureshi OS, Hewison M, et al. 1,25-Dihydroxyvitamin D3 and IL-2 combine to inhibit T cell production of inflammatory cytokines and promote development of regulatory $\mathrm{T}$ cells expressing CTLA-4 and FoxP3. J Immunol. (2009) 183:5458-67. doi: 10.4049/jimmunol.0803217

65. Kang SW, Kim SH, Lee N, Lee WW, Hwang KA, Shin MS, et al. 1,25Dihyroxyvitamin D3 promotes FOXP3 expression via binding to vitamin D response elements in its conserved noncoding sequence region. J Immunol. (2012) 188:5276-82. doi: 10.4049/jimmunol.1101211

66. Sharma MD, Hou DY, Liu Y, Koni PA, Metz R, Chandler P, et al. Indoleamine 2,3-dioxygenase controls conversion of Foxp3+ Tregs to TH17-like cells in tumor-draining lymph nodes. Blood. (2009) 113:6102-11. doi: 10.1182/blood-2008-12-195354

67. Baban B, Chandler PR, Sharma MD, Pihkala J, Koni PA, Munn DH, et al. IDO activates regulatory $\mathrm{T}$ cells and blocks their conversion into Th17-like T cells. J Immunol. (2009) 183:2475-83. doi: 10.4049/jimmunol.0900986

68. Yan Y, Zhang GX, Gran B, Fallarino F, Yu S, Li H, et al. IDO upregulates regulatory $\mathrm{T}$ cells via tryptophan catabolite and suppresses encephalitogenic $\mathrm{T}$ cell responses in experimental autoimmune encephalomyelitis. J Immunol. (2010) 185:5953-61. doi: 10.4049/jimmunol.1001628

69. Bender DA. Biochemistry of tryptophan in health and disease. Mol Aspects Med. (1983) 6:101-97. doi: 10.1016/0098-2997(83)90005-5

70. Anderson KA, Madsen AS, Olsen CA, Hirschey MD. Metabolic control by sirtuins and other enzymes that sense $\mathrm{NAD}(+), \mathrm{NADH}$, or their ratio. Biochim Biophys Acta Bioenerg. (2017) 1858:991-8. doi: 10.1016/j.bbabio.2017.09.005

71. Kwon HS, Lim HW, Wu J, Schnolzer M, Verdin E, Ott M. Three novel acetylation sites in the Foxp3 transcription factor regulate the suppressive activity of regulatory T cells. J Immunol. (2012) 188:2712-21. doi: 10.4049/jimmunol.1100903

72. van Loosdregt J, Brunen D, Fleskens V, Pals CE, Lam EW, Coffer PJ. Rapid temporal control of Foxp3 protein degradation by sirtuin-1. PLoS ONE. (2011) 6:e19047. doi: 10.1371/journal.pone.0019047

73. Schenk U, Frascoli M, Proietti M, Geffers R, Traggiai E, Buer J, et al. ATP inhibits the generation and function of regulatory $\mathrm{T}$ cells through the activation of purinergic P2X receptors. Sci Signal. (2011) 4:ra12. doi: 10.1126/scisignal.2001270

74. Borsellino G, Kleinewietfeld M, Di Mitri D, Sternjak A, Diamantini A, Giometto R, et al. Expression of ectonucleotidase CD39 by Foxp3+ Treg cells: hydrolysis of extracellular ATP and immune suppression. Blood. (2007) 110:1225-32. doi: 10.1182/blood-2006-12-064527

75. Patsoukis N, Bardhan K, Chatterjee P, Sari D, Liu B, Bell LN, et al. PD-1 alters T-cell metabolic reprogramming by inhibiting glycolysis and promoting lipolysis and fatty acid oxidation. Nat Commun. (2015) 6:6692. doi: $10.1038 /$ ncomms7692

76. Parry RV, Chemnitz JM, Frauwirth KA, Lanfranco AR, Braunstein I, Kobayashi SV, et al. CTLA-4 and PD-1 receptors inhibit T-cell activation by distinct mechanisms. Mol Cell Biol. (2005) 25:9543-53. doi: 10.1128/MCB.25.21.9543-9553.2005

77. Eleftheriadis T, Pissas G, Karioti A, Antoniadi G, Antoniadis N, Liakopoulos $\mathrm{V}$, et al. Dichloroacetate at therapeutic concentration alters glucose metabolism and induces regulatory T-cell differentiation in alloreactive human lymphocytes. J Basic Clin Physiol Pharmacol. (2013) 24:271-6. doi: 10.1515/jbcpp-2013-0001

78. Shi LZ, Wang R, Huang G, Vogel P, Neale G, Green DR, et al. HIF1alphadependent glycolytic pathway orchestrates a metabolic checkpoint for the differentiation of TH17 and Treg cells. J Exp Med. (2011) 208:1367-76. doi: 10.1084/jem.20110278

79. Wang R, Dillon CP, Shi LZ, Milasta S, Carter R, Finkelstein D, et al. The transcription factor Myc controls metabolic reprogramming upon T lymphocyte activation. Immunity. (2011) 35:871-82. doi: 10.1016/j.immuni.2011.09.021

80. De Rosa V, Galgani M, Porcellini A, Colamatteo A, Santopaolo M, Zuchegna $\mathrm{C}$, et al. Glycolysis controls the induction of human regulatory $\mathrm{T}$ cells by modulating the expression of FOXP3 exon 2 splicing variants. Nat Immunol. (2015) 16:1174-84. doi: 10.1038/ni.3269

81. Kishore M, Cheung KCP, Fu H, Bonacina F, Wang G, Coe D, et al. Regulatory $\mathrm{T}$ cell migration is dependent on glucokinase-mediated glycolysis. Immunity. (2018) 48:831-2. doi: 10.1016/j.immuni.2018.03.034

82. Beier UH, Angelin A, Akimova T, Wang L, Liu Y, Xiao H, et al. Essential role of mitochondrial energy metabolism in Foxp3 $(+)$ T-regulatory cell function and allograft survival. FASEB J. (2015) 29:2315-26. doi: 10.1096/fj.14-268409

83. Miska J, Lee-Chang C, Rashidi A, Muroski ME, Chang AL, Lopez-Rosas A, et al. HIF-1alpha is a metabolic switch between glycolytic-driven migration and oxidative phosphorylation-driven immunosuppression of Tregs in glioblastoma. Cell Rep. (2019) 27:226-37 e4. doi: 10.1016/j.celrep.2019.03.029

84. Weinberg SE, Singer BD, Steinert EM, Martinez CA, Mehta MM, Martinez-Reyes I, et al. Mitochondrial complex III is essential for suppressive function of regulatory T cells. Nature. (2019) 565:495-9. doi: 10.1038/s41586-018-0846-Z

85. Chapman NM, Zeng H, Nguyen TM, Wang Y, Vogel P, Dhungana Y, et al. mTOR coordinates transcriptional programs and mitochondrial metabolism of activated Treg subsets to protect tissue homeostasis. Nat Commun. (2018) 9:2095. doi: 10.1038/s41467-018-04392-5

86. Yu X, Lao $\mathrm{Y}$, Teng $\mathrm{XL}$, Li S, Zhou Y, Wang F, et al. SENP3 maintains the stability and function of regulatory $\mathrm{T}$ cells via $\mathrm{BACH} 2$ deSUMOylation. Nat Commun. (2018) 9:3157. doi: 10.1038/s41467-018-0 5676-6

87. Fu Z, Ye J, Dean JW, Bostick JW, Weinberg SE, Xiong L, et al. Requirement of mitochondrial transcription factor $\mathrm{A}$ in tissue-resident regulatory T cell maintenance and function. Cell Rep. (2019) 28:159-71 e4. doi: 10.1016/j.celrep.2019.06.024

88. Smith PM, Howitt MR, Panikov N, Michaud M, Gallini CA, Bohlooly YM, et al. The microbial metabolites, short-chain fatty acids, regulate colonic Treg cell homeostasis. Science. (2013) 341:569-73. doi: 10.1126/science.1 241165

89. Beier UH, Wang L, Han R, Akimova T, Liu Y, Hancock WW. Histone deacetylases 6 and 9 and sirtuin- 1 control Foxp3+ regulatory T cell function through shared and isoform-specific mechanisms. Sci Signal. (2012) 5:ra45. doi: $10.1126 /$ scisignal.2002873

90. van Loosdregt J, Vercoulen Y, Guichelaar T, Gent YY, Beekman JM, van Beekum O, et al. Regulation of Treg functionality by acetylationmediated Foxp3 protein stabilization. Blood. (2010) 115:965-74. doi: 10.1182/blood-2009-02-207118

91. Raud B, Roy DG, Divakaruni AS, Tarasenko TN, Franke R, Ma EH, et al. Etomoxir actions on regulatory and memory $\mathrm{T}$ cells are independent 
of Cptla-mediated fatty acid oxidation. Cell Metab. (2018) 28:504-15.e7. doi: 10.1016/j.cmet.2018.06.002

92. Porta C, Paglino C, Mosca A. Targeting PI3K/Akt/mTOR Signaling in Cancer. Front Oncol. (2014) 4:64. doi: 10.3389/fonc.2014.00064

93. Fan MY, Turka LA. Immunometabolism and PI(3)K signaling as a link between IL-2, Foxp3 expression, and suppressor function in regulatory $\mathrm{T}$ cells. Front Immunol. (2018) 9:69. doi: 10.3389/fimmu.2018.00069

94. Hedrick SM, Hess Michelini R, Doedens AL, Goldrath AW, Stone EL. FOXO transcription factors throughout T cell biology. Nat Rev Immunol. (2012) 12:649-61. doi: 10.1038/nri3278

95. Ouyang W, Liao W, Luo CT, Yin N, Huse M, Kim MV, et al. Novel Foxo1dependent transcriptional programs control $\mathrm{T}(\mathrm{reg})$ cell function. Nature. (2012) 491:554-9. doi: 10.1038/nature11581

96. Ouyang W, Beckett O, Ma Q, Paik JH, DePinho RA, Li MO. Foxo proteins cooperatively control the differentiation of Foxp3+ regulatory T cells. Nat Immunol. (2010) 11:618-27. doi: 10.1038/ni.1884

97. Crellin NK, Garcia RV, Levings MK. Altered activation of AKT is required for the suppressive function of human CD4+CD25+ T regulatory cells. Blood. (2007) 109:2014-22. doi: 10.1182/blood-2006-07-035279

98. Newton RH, Shrestha S, Sullivan JM, Yates KB, Compeer EB, Ron-Harel N, et al. Maintenance of CD4 T cell fitness through regulation of Foxo1. Nat Immunol. (2018) 19:838-48. doi: 10.1038/s41590-018-0157-4

99. Delgoffe GM, Woo SR, Turnis ME, Gravano DM, Guy C, Overacre AE, et al. Stability and function of regulatory $\mathrm{T}$ cells is maintained by a neuropilin-1semaphorin-4a axis. Nature. (2013) 501:252-6. doi: 10.1038/nature12428

100. Chi H. Regulation and function of mTOR signalling in T cell fate decisions. Nat Rev Immunol. (2012) 12:325-38. doi: 10.1038/nri3198

101. MacIver NJ, Michalek RD, Rathmell JC. Metabolic regulation of T lymphocytes. Annu Rev Immunol. (2013) 31:259-83. doi: 10.1146/annurev-immunol-032712-095956

102. Sauer S, Bruno L, Hertweck A, Finlay D, Leleu M, Spivakov M, et al. T cell receptor signaling controls Foxp3 expression via PI3K, Akt, and mTOR. Proc Natl Acad Sci USA. (2008) 105:7797-802. doi: 10.1073/pnas.0800928105

103. Park Y, Jin HS, Lopez J, Elly C, Kim G, Murai M, et al. TSC1 regulates the balance between effector and regulatory T cells. J Clin Invest. (2013) 123:5165-78. doi: 10.1172/JCI69751

104. Delgoffe GM, Pollizzi KN, Waickman AT, Heikamp E, Meyers DJ, Horton $\mathrm{MR}$, et al. The kinase mTOR regulates the differentiation of helper $\mathrm{T}$ cells through the selective activation of signaling by mTORC1 and mTORC2. Nat Immunol. (2011) 12:295-303. doi: 10.1038/ni.2005

105. Lee K, Gudapati P, Dragovic S, Spencer C, Joyce S, Killeen N, et al. Mammalian target of rapamycin protein complex 2 regulates differentiation of Th1 and Th2 cell subsets via distinct signaling pathways. Immunity. (2010) 32:743-53. doi: 10.1016/j.immuni.2010.06.002

106. Charbonnier LM, Cui Y, Stephen-Victor E, Harb H, Lopez D, Bleesing JJ, et al. Functional reprogramming of regulatory $\mathrm{T}$ cells in the absence of Foxp3. Nat Immunol. (2019). doi: 10.1038/s41590-019-0442-x

107. Walsh PT, Buckler JL, Zhang J, Gelman AE, Dalton NM, Taylor DK, et al. PTEN inhibits IL-2 receptor-mediated expansion of CD4+ CD25+ Tregs. J Clin Invest. (2006) 116:2521-31. doi: 10.1172/JCI28057

108. Procaccini C, De Rosa V, Galgani M, Abanni L, Cali G, Porcellini $A$, et al. An oscillatory switch in mTOR kinase activity sets regulatory $\mathrm{T}$ cell responsiveness. Immunity. (2010) 33:929-41. doi: 10.1016/j.immuni.2010.11.024

109. Shaw RJ. LKB1 and AMP-activated protein kinase control of mTOR signalling and growth. Acta Physiol. (2009) 196:65-80. doi: 10.1111/j.1748-1716.2009.01972.x

110. Herzig S, Shaw RJ. AMPK: guardian of metabolism and mitochondrial homeostasis. Nat Rev Mol Cell Biol. (2018) 19:121-35. doi: $10.1038 / \mathrm{nrm} .2017 .95$

111. van der Windt GJ, Pearce EL. Metabolic switching and fuel choice during Tcell differentiation and memory development. Immunol Rev. (2012) 249:2742. doi: 10.1111/j.1600-065X.2012.01150.x

112. Gualdoni GA, Mayer KA, Goschl L, Boucheron N, Ellmeier W, Zlabinger GJ. The AMP analog AICAR modulates the Treg/Th17 axis through enhancement of fatty acid oxidation. FASEB J. (2016) 30:3800-9. doi: 10.1096/fj.201600522R
113. Yang K, Blanco DB, Neale G, Vogel P, Avila J, Clish CB, et al. Homeostatic control of metabolic and functional fitness of Treg cells by LKB1 signalling. Nature. (2017) 548:602-6. doi: 10.1038/nature23665

114. Wu D, Luo Y, Guo W, Niu Q, Xue T, Yang F, et al. Lkb1 maintains Treg cell lineage identity. Nat Commun. (2017) 8:15876. doi: 10.1038/ncomms15876

115. Timilshina M, You Z, Lacher SM, Acharya S, Jiang L, Kang Y, et al. Activation of mevalonate pathway via LKB1 is essential for stability of Treg cells. Cell Rep. (2019) 27:2948-61 e7. doi: 10.1016/j.celrep.2019.05.020

116. He N, Fan W, Henriquez B, Yu RT, Atkins AR, Liddle C, et al. Metabolic control of regulatory T cell (Treg) survival and function by Lkb1. Proc Natl Acad Sci USA. (2017) 114:12542-7. doi: 10.1073/pnas.1715363114

117. Koch MA, Thomas KR, Perdue NR, Smigiel KS, Srivastava S, Campbell DJ. T-bet(+) Treg cells undergo abortive Th1 cell differentiation due to impaired expression of IL-12 receptor beta2. Immunity. (2012) 37:501-10. doi: 10.1016/j.immuni.2012.05.031

118. Levine AG, Mendoza A, Hemmers S, Moltedo B, Niec RE, Schizas M, et al. Stability and function of regulatory $\mathrm{T}$ cells expressing the transcription factor T-bet. Nature. (2017) 546:421-5. doi: 10.1038/nature22360

119. Zheng Y, Chaudhry A, Kas A, deRoos P, Kim JM, Chu TT, et al. Regulatory Tcell suppressor program co-opts transcription factor IRF4 to control T(H)2 responses. Nature. (2009) 458:351-6. doi: 10.1038/nature07674

120. Chaudhry A, Rudra D, Treuting P, Samstein RM, Liang Y, Kas A, et al. CD4+ regulatory T cells control TH17 responses in a Stat3-dependent manner. Science. (2009) 326:986-91. doi: 10.1126/science.1172702

121. Harrison OJ, Linehan JL, Shih HY, Bouladoux N, Han SJ, Smelkinson M, et al. Commensal-specific $\mathrm{T}$ cell plasticity promotes rapid tissue adaptation to injury. Science. (2019) 363:eaat6280. doi: 10.1126/science.aat6280

122. Rudra D, deRoos P, Chaudhry A, Niec RE, Arvey A, Samstein RM, et al. Transcription factor Foxp3 and its protein partners form a complex regulatory network. Nat Immunol. (2012) 13:1010-9. doi: 10.1038/ni.2402

123. Wang Y, Su MA, Wan YY. An essential role of the transcription factor GATA-3 for the function of regulatory T cells. Immunity. (2011) 35:337-48. doi: 10.1016/j.immuni.2011.08.012

124. Wohlfert EA, Grainger JR, Bouladoux N, Konkel JE, Oldenhove G, Ribeiro $\mathrm{CH}$, et al. GATA3 controls Foxp3(+) regulatory $\mathrm{T}$ cell fate during inflammation in mice. J Clin Invest. (2011) 121:4503-15. doi: $10.1172 /$ JCI57456

125. Yu F, Sharma S, Edwards J, Feigenbaum L, Zhu J. Dynamic expression of transcription factors T-bet and GATA-3 by regulatory T cells maintains immunotolerance. Nat Immunol. (2015) 16:197-206. doi: 10.1038/ni.3053

126. Chung Y, Tanaka S, Chu F, Nurieva RI, Martinez GJ, Rawal S, et al. Follicular regulatory $\mathrm{T}$ cells expressing Foxp3 and Bcl-6 suppress germinal center reactions. Nat Med. (2011) 17:983-8. doi: 10.1038/nm.2426

127. Wollenberg I, Agua-Doce A, Hernandez A, Almeida C, Oliveira VG, Faro J, et al. Regulation of the germinal center reaction by Foxp3+ follicular regulatory T cells. J Immunol. (2011) 187:4553-60. doi: 10.4049/jimmunol.1101328

128. Linterman MA, Pierson W, Lee SK, Kallies A, Kawamoto S, Rayner TF, et al. Foxp3+ follicular regulatory $\mathrm{T}$ cells control the germinal center response. Nat Med. (2011) 17:975-82. doi: 10.1038/nm.2425

129. Dominguez-Villar M, Baecher-Allan CM, Hafler DA. Identification of T helper type 1-like, Foxp3+ regulatory T cells in human autoimmune disease. Nat Med. (2011) 17:673-5. doi: 10.1038/nm.2389

130. Butcher MJ, Filipowicz AR, Waseem TC, McGary CM, Crow KJ, Magilnick $\mathrm{N}$, et al. Atherosclerosis-driven Treg plasticity results in formation of a dysfunctional subset of plastic IFNgamma+ Th1/Tregs. Circ Res. (2016) 119:1190-203. doi: 10.1161/CIRCRESAHA.116.309764

131. Kitz A, de Marcken M, Gautron AS, Mitrovic M, Hafler DA, DominguezVillar M. AKT isoforms modulate Th1-like Treg generation and function in human autoimmune disease. EMBO Rep. (2016) 17:1169-83. doi: 10.15252/embr.201541905

132. McClymont SA, Putnam AL, Lee MR, Esensten JH, Liu W, Hulme $\mathrm{MA}$, et al. Plasticity of human regulatory $\mathrm{T}$ cells in healthy subjects and patients with type 1 diabetes. J Immunol. (2011) 186:3918-26. doi: 10.4049/jimmunol.1003099

133. Yamada A, Ushio A, Arakaki R, Tsunematsu T, Kudo Y, Hayashi $\mathrm{Y}$, et al. Impaired expansion of regulatory $\mathrm{T}$ cells in a neonatal 
thymectomy-induced autoimmune mouse model. Am J Pathol. (2015) 185:2886-97. doi: 10.1016/j.ajpath.2015.07.007

134. Overacre-Delgoffe AE, Chikina M, Dadey RE, Yano H, Brunazzi EA, Shayan G, et al. Interferon-gamma drives Treg fragility to promote antitumor immunity. Cell. (2017) 169:1130-41 e11. doi: 10.1016/j.cell.2017. 05.005

135. Di Pilato M, Kim EY, Cadilha BL, Prussmann JN, Nasrallah MN, Seruggia D, et al. Targeting the CBM complex causes Treg cells to prime tumours for immune checkpoint therapy. Nature. (2019) 570:112-6. doi: 10.1038/s41586-019-1215-2

136. Arterbery AS, Osafo-Addo A, Avitzur Y, Ciarleglio M, Deng Y, Lobritto SJ, et al. Production of proinflammatory cytokines by monocytes in livertransplanted recipients with de novo autoimmune hepatitis is enhanced and induces TH1-like regulatory T cells. J Immunol. (2016) 196:4040-51. doi: $10.4049 /$ jimmunol.1502276

137. Xu L, Huang Q, Wang H, Hao Y, Bai Q, Hu J, et al. The kinase mTORC1 promotes the generation and suppressive function of follicular regulatory $\mathrm{T}$ cells. Immunity. (2017) 47:538-51.e5. doi: 10.1016/j.immuni.2017.08.011

138. Peng M, Yin N, Chhangawala S, Xu K, Leslie CS, Li MO. Aerobic glycolysis promotes $\mathrm{T}$ helper 1 cell differentiation through an epigenetic mechanism. Science. (2016) 354:481-4. doi: 10.1126/science.aaf6284

139. Lee JH, Elly C, Park Y, Liu YC. E3 Ubiquitin Ligase VHL Regulates hypoxia-inducible factor-1alpha to maintain regulatory $\mathrm{T}$ cell stability and suppressive capacity. Immunity. (2015) 42:1062-74. doi: 10.1016/j.immuni.2015.05.016

140. Noval Rivas M, Burton OT, Wise P, Charbonnier LM, Georgiev P, Oettgen $\mathrm{HC}$, et al. Regulatory $\mathrm{T}$ cell reprogramming toward a Th2-cell-like lineage impairs oral tolerance and promotes food allergy. Immunity. (2015) 42:51223. doi: 10.1016/j.immuni.2015.02.004

141. Krishnamoorthy N, Khare A, Oriss TB, Raundhal M, Morse C, Yarlagadda $\mathrm{M}$, et al. Early infection with respiratory syncytial virus impairs regulatory $\mathrm{T}$ cell function and increases susceptibility to allergic asthma. Nat Med. (2012) 18:1525-30. doi: $10.1038 / \mathrm{nm} .2896$

142. Jin HS, Park Y, Elly C, Liu YC. Itch expression by Treg cells controls Th2 inflammatory responses. J Clin Invest. (2013) 123:4923-34. doi: 10.1172/JCI69355

143. Levine AG, Arvey A, Jin W, Rudensky AY. Continuous requirement for the TCR in regulatory T cell function. Nat Immunol. (2014) 15:1070-8. doi: 10.1038/ni.3004

144. Ayyoub M, Deknuydt F, Raimbaud I, Dousset C, Leveque L, Bioley G, et al. Human memory FOXP3+ Tregs secrete IL-17 ex vivo and constitutively express the $\mathrm{T}(\mathrm{H}) 17$ lineage-specific transcription factor RORgamma t. Proc Natl Acad Sci USA. (2009) 106:8635-40. doi: 10.1073/pnas.0900621106

145. Voo KS, Wang YH, Santori FR, Boggiano C, Wang YH, Arima K, et al. Identification of IL-17-producing FOXP3+ regulatory T cells in humans. Proc Natl Acad Sci USA. (2009) 106:4793-8. doi: 10.1073/pnas.0900408106

146. Kim BS, Lu H, Ichiyama $\mathrm{K}$, Chen $\mathrm{X}$, Zhang $\mathrm{YB}$, Mistry NA, et al. Generation of RORgammat(+) Antigen-Specific T Regulatory 17 Cells from Foxp3(+) Precursors in Autoimmunity. Cell Rep. (2017) 21:195-207. doi: 10.1016/j.celrep.2017.09.021

147. Beriou G, Costantino CM, Ashley CW, Yang L, Kuchroo VK, Baecher-Allan C, et al. IL-17-producing human peripheral regulatory $\mathrm{T}$ cells retain suppressive function. Blood. (2009) 113:4240-9. doi: 10.1182/blood-2008-10-183251

148. Osorio F, LeibundGut-Landmann S, Lochner M, Lahl K, Sparwasser T, Eberl G, et al. DC activated via dectin-1 convert Treg into IL-17 producers. Eur J Immunol. (2008) 38:3274-81. doi: 10.1002/eji.200838950

149. Li L, Kim J, Boussiotis VA. IL-1beta-mediated signals preferentially drive conversion of regulatory $\mathrm{T}$ cells but not conventional $\mathrm{T}$ cells into IL-17-producing cells. J Immunol. (2010) 185:4148-53. doi: 10.4049/jimmunol.1001536

150. Yang XO, Nurieva R, Martinez GJ, Kang HS, Chung Y, Pappu BP, et al. Molecular antagonism and plasticity of regulatory and inflammatory $\mathrm{T}$ cell programs. Immunity. (2008) 29:44-56. doi: 10.1016/j.immuni.2008.05.007

151. Duncan KD, Fyrestam J, Lanekoff I. Advances in mass spectrometry based single-cell metabolomics. Analyst. (2019) 144:782-93. doi: 10.1039/C8AN01581C
152. Zenobi R. Single-cell metabolomics: analytical and biological perspectives. Science. (2013) 342:1243259. doi: 10.1126/science.1243259

153. Sun IH, Oh MH, Zhao L, Patel CH, Arwood ML, Xu W, et al. mTOR complex 1 signaling regulates the generation and function of central and effector Foxp3(+) regulatory T cells. J Immunol. (2018) 201:481-92. doi: 10.4049/jimmunol.1701477

154. Feuerer M, Herrero L, Cipolletta D, Naaz A, Wong J, Nayer A, et al. Lean, but not obese, fat is enriched for a unique population of regulatory $\mathrm{T}$ cells that affect metabolic parameters. Nat Med. (2009) 15:930-9. doi: 10.1038/nm.2002

155. Cipolletta D, Feuerer M, Li A, Kamei N, Lee J, Shoelson SE, et al. PPARgamma is a major driver of the accumulation and phenotype of adipose tissue Treg cells. Nature. (2012) 486:549-53. doi: 10.1038/nature11132

156. De Rosa V, Procaccini C, Cali G, Pirozzi G, Fontana S, Zappacosta S, et al. A key role of leptin in the control of regulatory $\mathrm{T}$ cell proliferation. Immunity. (2007) 26:241-55. doi: 10.1016/j.immuni.2007.01.011

157. Myers MG, Cowley MA, Munzberg H. Mechanisms of leptin action and leptin resistance. Annu Rev Physiol. (2008) 70:537-56. doi: 10.1146/annurev.physiol.70.113006.100707

158. Schmidleithner L, Thabet Y, Schonfeld E, Kohne M, Sommer D, Abdullah Z, et al. Enzymatic activity of HPGD in Treg cells suppresses Tconv cells to maintain adipose tissue homeostasis and prevent metabolic dysfunction. Immunity. (2019) 50:1232-48.e14. doi: 10.1016/j.immuni.2019.03.014

159. Li C, DiSpirito JR, Zemmour D, Spallanzani RG, Kuswanto W, Benoist C, et al. TCR transgenic mice reveal stepwise, multi-site acquisition of the distinctive fat-Treg phenotype. Cell. (2018) 174:285-99 el2. doi: 10.1016/j.cell.2018.05.004

160. Kolodin D, van Panhuys N, Li C, Magnuson AM, Cipolletta D, Miller $\mathrm{CM}$, et al. Antigen- and cytokine-driven accumulation of regulatory $\mathrm{T}$ cells in visceral adipose tissue of lean mice. Cell Metab. (2015) 21:543-57. doi: 10.1016/j.cmet.2015.03.005

161. Vasanthakumar A, Moro K, Xin A, Liao Y, Gloury R, Kawamoto S, et al. The transcriptional regulators IRF4, BATF and IL-33 orchestrate development and maintenance of adipose tissue-resident regulatory T cells. Nat Immunol. (2015) 16:276-85. doi: 10.1038/ni.3085

162. Griesenauer B, Paczesny S. The ST2/IL-33 axis in immune cells during inflammatory diseases. Front Immunol. (2017) 8:475. doi: 10.3389/fimmu.2017.00475

163. Kohlgruber AC, Gal-Oz ST, LaMarche NM, Shimazaki M, Duquette D, Koay $\mathrm{HF}$, et al. gammadelta $\mathrm{T}$ cells producing interleukin-17A regulate adipose regulatory T cell homeostasis and thermogenesis. Nat Immunol. (2018) 19:464-74. doi: 10.1038/s41590-018-0094-2

164. Ito M, Komai K, Mise-Omata S, Iizuka-Koga M, Noguchi Y, Kondo T, et al. Brain regulatory $\mathrm{T}$ cells suppress astrogliosis and potentiate neurological recovery. Nature. (2019) 565:246-50. doi: 10.1038/s41586-018-0824-5

165. Schiering C, Krausgruber T, Chomka A, Frohlich A, Adelmann K, Wohlfert EA, et al. The alarmin IL-33 promotes regulatory T-cell function in the intestine. Nature. (2014) 513:564-8. doi: 10.1038/nature13577

166. Deng T, Liu J, Deng YR, Minze L, Xiang X, Wright V, et al. Adipocyte adaptive immunity mediates diet-induced adipose inflammation and insulin resistance by decreasing adipose Treg cells. Nat Commun. (2017) 8:15725. doi: $10.1038 /$ ncomms 15725

167. Onodera T, Fukuhara A, Jang MH, Shin J, Aoi K, Kikuta J, et al. Adipose tissue macrophages induce PPARgamma-high FOXP3(+) regulatory T cells. Sci Rep. (2015) 5:16801. doi: 10.1038/srep16801

168. Agace WW, McCoy KD. Regionalized development and maintenance of the intestinal adaptive immune landscape. Immunity. (2017) 46:532-48. doi: 10.1016/j.immuni.2017.04.004

169. Whibley N, Tucci A, Powrie F. Regulatory T cell adaptation in the intestine and skin. Nat Immunol. (2019) 20:386-96. doi: 10.1038/s41590-019-0351-z

170. Ohnmacht C, Park JH, Cording S, Wing JB, Atarashi K, Obata Y, et al. MUCOSAL IMMUNOLOGY. The microbiota regulates type 2 immunity through RORgammat(+) T cells. Science. (2015) 349:989-93. doi: $10.1126 /$ science.aac4263

171. Zhou L, Lopes JE, Chong MM, Ivanov, II, Min R, Victora GD, et al. TGFbeta-induced Foxp3 inhibits $\mathrm{T}(\mathrm{H}) 17$ cell differentiation by antagonizing RORgammat function. Nature. (2008) 453:236-40. doi: 10.1038/nature06878 
172. Lochner M, Peduto L, Cherrier M, Sawa S, Langa F, Varona R, et al. In vivo equilibrium of proinflammatory $\mathrm{IL}-17+$ and regulatory IL10+ Foxp3+ RORgamma t+ T cells. J Exp Med. (2008) 205:1381-93. doi: $10.1084 /$ jem.20080034

173. Sefik E, Geva-Zatorsky N, Oh S, Konnikova L, Zemmour D, McGuire AM, et al. MUCOSAL IMMUNOLOGY. Individual intestinal symbionts induce a distinct population of RORgamma $(+)$ regulatory T cells. Science. (2015) 349:993-7. doi: 10.1126/science.aaa9420

174. Yang BH, Hagemann S, Mamareli P, Lauer U, Hoffmann U, Beckstette M, et al. Foxp3(+) T cells expressing RORgammat represent a stable regulatory T-cell effector lineage with enhanced suppressive capacity during intestinal inflammation. Mucosal Immunol. (2016) 9:444-57. doi: 10.1038/mi.2015.74

175. Kim KS, Hong SW, Han D, Yi J, Jung J, Yang BG, et al. Dietary antigens limit mucosal immunity by inducing regulatory $\mathrm{T}$ cells in the small intestine. Science. (2016) 351:858-63. doi: 10.1126/science.aac5560

176. Solomon BD, Hsieh CS. Antigen-specific development of mucosal Foxp3+RORgammat $+\mathrm{T}$ cells from regulatory T cell precursors. J Immunol. (2016) 197:3512-9. doi: 10.4049/jimmunol.1601217

177. Lathrop SK, Bloom SM, Rao SM, Nutsch K, Lio CW, Santacruz N, et al. Peripheral education of the immune system by colonic commensal microbiota. Nature. (2011) 478:250-4. doi: 10.1038/nature10434

178. Nutsch K, Chai JN, Ai TL, Russler-Germain E, Feehley T, Nagler CR, et al. Rapid and efficient generation of regulatory $\mathrm{T}$ Cells to commensal antigens in the periphery. Cell Rep. (2016) 17:206-20. doi: 10.1016/j.celrep.2016.08.092

179. Ye J, Qiu J, Bostick JW, Ueda A, Schjerven H, Li S, et al. The aryl hydrocarbon receptor preferentially marks and promotes gut regulatory T cells. Cell Rep. (2017) 21:2277-90. doi: 10.1016/j.celrep.2017.10.114

180. Atarashi K, Tanoue T, Oshima K, Suda W, Nagano Y, Nishikawa H, et al. Treg induction by a rationally selected mixture of Clostridia strains from the human microbiota. Nature. (2013) 500:232-6. doi: 10.1038/nature12331

181. Chai JN, Peng Y, Rengarajan S, Solomon BD, Ai TL, Shen Z, et al. Helicobacter species are potent drivers of colonic $\mathrm{T}$ cell responses in homeostasis and inflammation. Sci Immunol. (2017) 2:eaal5068. doi: 10.1126/sciimmunol.aal5068

182. Atarashi K, Tanoue T, Shima T, Imaoka A, Kuwahara T, Momose Y, et al. Induction of colonic regulatory $\mathrm{T}$ cells by indigenous Clostridium species. Science. (2011) 331:337-41. doi: 10.1126/science.1198469

183. Xu M, Pokrovskii M, Ding Y, Yi R, Au C, Harrison OJ, et al. c-MAFdependent regulatory $\mathrm{T}$ cells mediate immunological tolerance to a gut pathobiont. Nature. (2018) 554:373-7. doi: 10.1038/nature25500

184. Shinde R, McGaha TL. The aryl hydrocarbon receptor: connecting immunity to the microenvironment. Trends Immunol. (2018) 39:1005-20. doi: 10.1016/j.it.2018.10.010

185. Zelante T, Iannitti RG, Cunha C, De Luca A, Giovannini G, Pieraccini $\mathrm{G}$, et al. Tryptophan catabolites from microbiota engage aryl hydrocarbon receptor and balance mucosal reactivity via interleukin-22. Immunity. (2013) 39:372-85. doi: 10.1016/j.immuni.2013.08.003

186. Mezrich JD, Fechner JH, Zhang X, Johnson BP, Burlingham WJ, Bradfield CA. An interaction between kynurenine and the aryl hydrocarbon receptor can generate regulatory T cells. J Immunol. (2010) 185:3190-8. doi: 10.4049/jimmunol.0903670

187. Kim SV, Xiang WV, Kwak C, Yang Y, Lin XW, Ota M, et al. GPR15-mediated homing controls immune homeostasis in the large intestine mucosa. Science. (2013) 340:1456-9. doi: 10.1126/science.1237013

188. Geuking MB, Cahenzli J, Lawson MA, Ng DC, Slack E, Hapfelmeier S, et al. Intestinal bacterial colonization induces mutualistic regulatory $\mathrm{T}$ cell responses. Immunity. (2011) 34:794-806. doi: 10.1016/j.immuni.2011.03.021

189. Kang SG, Lim HW, Andrisani OM, Broxmeyer HE, Kim CH. Vitamin A metabolites induce gut-homing FoxP3+ regulatory $\mathrm{T}$ cells. J Immunol. (2007) 179:3724-33. doi: 10.4049/jimmunol.179.6.3724

190. Coombes JL, Siddiqui KR, Arancibia-Carcamo CV, Hall J, Sun CM, Belkaid Y, et al. A functionally specialized population of mucosal CD103+ DCs induces Foxp3 + regulatory $\mathrm{T}$ cells via a TGF-beta and retinoic acid-dependent mechanism. J Exp Med. (2007) 204:1757-64. doi: 10.1084/jem.20070590

191. Jaensson-Gyllenback E, Kotarsky K, Zapata F, Persson EK, Gundersen TE, Blomhoff $\mathrm{R}$, et al. Bile retinoids imprint intestinal CD103+ dendritic cells with the ability to generate gut-tropic T cells. Mucosal Immunol. (2011) 4:438-47. doi: 10.1038/mi.2010.91
192. McDonald KG, Leach MR, Brooke KW, Wang C, Wheeler LW, Hanly EK, et al. Epithelial expression of the cytosolic retinoid chaperone cellular retinol binding protein II is essential for in vivo imprinting of local gut dendritic cells by lumenal retinoids. Am J Pathol. (2012) 180:984-97. doi: 10.1016/j.ajpath.2011.11.009

193. Cassani B, Villablanca EJ, Quintana FJ, Love PE, Lacy-Hulbert A, Blaner WS, et al. Gut-tropic T cells that express integrin alpha4beta7 and CCR9 are required for induction of oral immune tolerance in mice. Gastroenterology. (2011) 141:2109-18. doi: 10.1053/j.gastro.2011.09.015

194. Ikeda K, Kinoshita M, Kayama H, Nagamori S, Kongpracha P, Umemoto E, et al. Slc3a2 mediates branched-chain amino-acid-dependent maintenance of regulatory $\mathrm{T}$ cells. Cell Rep. (2017) 21:1824-38. doi: 10.1016/j.celrep.2017.10.082

195. Liu C, Workman CJ, Vignali DA. Targeting regulatory $\mathrm{T}$ cells in tumors. FEBS J. (2016) 283:2731-48. doi: 10.1111/febs.13656

196. Chao JL, Savage PA. Unlocking the complexities of tumorassociated regulatory $\mathrm{T}$ cells. J Immunol. (2018) 200:415-21. doi: 10.4049/jimmunol.1701188

197. Gonzalez H, Hagerling C, Werb Z. Roles of the immune system in cancer: from tumor initiation to metastatic progression. Genes Dev. (2018) 32:126784. doi: 10.1101/gad.314617.118

198. Pavlova NN, Thompson CB. The emerging hallmarks of cancer metabolism. Cell Metab. (2016) 23:27-47. doi: 10.1016/j.cmet.2015.12.006

199. Magnuson AM, Kiner E, Ergun A, Park JS, Asinovski N, Ortiz-Lopez A, et al. Identification and validation of a tumor-infiltrating Treg transcriptional signature conserved across species and tumor types. Proc Natl Acad Sci USA. (2018) 115:E10672-81. doi: 10.1073/pnas.1810580115

200. Luo CT, Liao W, Dadi S, Toure A, Li MO. Graded Foxo1 activity in Treg cells differentiates tumour immunity from spontaneous autoimmunity. Nature. (2016) 529:532-6. doi: 10.1038/nature16486

201. Ali K, Soond DR, Pineiro R, Hagemann T, Pearce W, Lim EL, et al. Inactivation of $\mathrm{PI}(3) \mathrm{K}$ p110delta breaks regulatory T-cell-mediated immune tolerance to cancer. Nature. (2014) 510:407-11. doi: 10.1038/nature13444

202. Abu-Eid R, Samara RN, Ozbun L, Abdalla MY, Berzofsky JA, Friedman $\mathrm{KM}$, et al. Selective inhibition of regulatory $\mathrm{T}$ cells by targeting the PI3K-Akt pathway. Cancer Immunol Res. (2014) 2:1080-9. doi: 10.1158/2326-6066.CIR-14-0095

203. Ahmad S, Abu-Eid R, Shrimali R, Webb M, Verma V, Doroodchi A, et al. Differential PI3Kdelta signaling in CD4(+) T-cell subsets enables selective targeting of $\mathrm{T}$ regulatory cells to enhance cancer immunotherapy. Cancer Res. (2017) 77:1892-904. doi: 10.1158/0008-5472.CAN-16-1839

204. Plitas G, Konopacki C, Wu K, Bos PD, Morrow M, Putintseva EV, et al. Regulatory $\mathrm{T}$ cells exhibit distinct features in human breast cancer. Immunity. (2016) 45:1122-34. doi: 10.1016/j.immuni.2016.10.032

205. Herbel C, Patsoukis N, Bardhan K, Seth P, Weaver JD, Boussiotis VA. Clinical significance of $\mathrm{T}$ cell metabolic reprogramming in cancer. Clin Transl Med. (2016) 5:29. doi: 10.1186/s40169-016-0110-9

206. Sugiura A, Rathmell JC. Metabolic barriers to T cell function in tumors. $J$ Immunol. (2018) 200:400-7. doi: 10.4049/jimmunol.1701041

207. Macintyre AN, Gerriets VA, Nichols AG, Michalek RD, Rudolph MC, Deoliveira D, et al. The glucose transporter Glut1 is selectively essential for CD4 T cell activation and effector function. Cell Metab. (2014) 20:61-72. doi: 10.1016/j.cmet.2014.05.004

208. Wei J, Raynor J, Nguyen TL, Chi H. Nutrient and metabolic sensing in T cell responses. Front Immunol. (2017) 8:247. doi: 10.3389/fimmu.2017.00247

209. Nakaya M, Xiao Y, Zhou X, Chang JH, Chang M, Cheng X, et al. Inflammatory $\mathrm{T}$ cell responses rely on amino acid transporter ASCT2 facilitation of glutamine uptake and mTORC1 kinase activation. Immunity. (2014) 40:692-705. doi: 10.1016/j.immuni.2014. 04.007

210. Sinclair LV, Rolf J, Emslie E, Shi YB, Taylor PM, Cantrell DA. Control of amino-acid transport by antigen receptors coordinates the metabolic reprogramming essential for $\mathrm{T}$ cell differentiation. Nat Immunol. (2013) 14:500-8. doi: 10.1038/ni.2556

211. Klysz D, Tai X, Robert PA, Craveiro M, Cretenet G, Oburoglu L, et al. Glutamine-dependent alpha-ketoglutarate production regulates the balance between T helper 1 cell and regulatory T cell generation. Sci Signal. (2015) 8:ra97. doi: 10.1126/scisignal.aab2610 
212. Cobbold SP, Adams E, Farquhar CA, Nolan KF, Howie D, Lui KO, et al. Infectious tolerance via the consumption of essential amino acids and mTOR signaling. Proc Natl Acad Sci USA. (2009) 106:12055-60. doi: 10.1073/pnas.0903919106

213. Furusawa Y, Obata Y, Fukuda S, Endo TA, Nakato G, Takahashi D, et al. Commensal microbe-derived butyrate induces the differentiation of colonic regulatory T cells. Nature. (2013) 504:446-50. doi: 10.1038/nature12721

214. Pacella I, Procaccini C, Focaccetti C, Miacci S, Timperi E, Faicchia D, et al. Fatty acid metabolism complements glycolysis in the selective regulatory T cell expansion during tumor growth. Proc Natl Acad Sci USA. (2018) 115:E6546-55. doi: 10.1073/pnas.1720113115

215. Eales KL, Hollinshead KE, Tennant DA. Hypoxia and metabolic adaptation of cancer cells. Oncogenesis. (2016) 5:e190. doi: 10.1038/oncsis.2015.50

216. Iommarini L, Porcelli AM, Gasparre G, Kurelac I. Non-canonical mechanisms regulating hypoxia-inducible factor 1 alpha in cancer. Front Oncol. (2017) 7:286. doi: 10.3389/fonc.2017.00286

217. Dang EV, Barbi J, Yang HY, Jinasena D, Yu H, Zheng Y, et al. Control of $\mathrm{T}(\mathrm{H}) 17 / \mathrm{T}$ (reg) balance by hypoxia-inducible factor 1. Cell. (2011) 146:77284. doi: 10.1016/j.cell.2011.07.033

218. Clambey ET, McNamee EN, Westrich JA, Glover LE, Campbell EL, Jedlicka $\mathrm{P}$, et al. Hypoxia-inducible factor-1 alpha-dependent induction of FoxP3 drives regulatory T-cell abundance and function during inflammatory hypoxia of the mucosa. Proc Natl Acad Sci USA. (2012) 109:E2784-93. doi: 10.1073/pnas.1202366109

219. Fischer K, Hoffmann P, Voelkl S, Meidenbauer N, Ammer J, Edinger M, et al. Inhibitory effect of tumor cell-derived lactic acid on human T cells. Blood. (2007) 109:3812-9. doi: 10.1182/blood-2006-07-035972

220. Mendler AN, Hu B, Prinz PU, Kreutz M, Gottfried E, Noessner E. Tumor lactic acidosis suppresses CTL function by inhibition of p38 and JNK/c-Jun activation. Int J Cancer. (2012) 131:633-40. doi: 10.1002/ijc. 26410

221. Pilon-Thomas S, Kodumudi KN, El-Kenawi AE, Russell S, Weber AM, Luddy $\mathrm{K}$, et al. Neutralization of tumor acidity improves antitumor responses to immunotherapy. Cancer Res. (2016) 76:1381-90. doi: 10.1158/0008-5472.CAN-15-1743
222. Maj T, Wang W, Crespo J, Zhang H, Wang W, Wei S, et al. Oxidative stress controls regulatory $\mathrm{T}$ cell apoptosis and suppressor activity and PD-L1-blockade resistance in tumor. Nat Immunol. (2017) 18:1332-41. doi: 10.1038/ni.3868

223. Xiao Z, Dai Z, Locasale JW. Metabolic landscape of the tumor microenvironment at single cell resolution. Nat Commun. (2019) 10:3763. doi: 10.1038/s41467-019-11738-0

224. Karmaus PWF, Chen X, Lim SA, Herrada AA, Nguyen TM, Xu B, et al. Metabolic heterogeneity underlies reciprocal fates of TH17 cell stemness and plasticity. Nature. (2019) 565:101-5. doi: 10.1038/s41586-018-0806-7

225. Miragaia RJ, Gomes T, Chomka A, Jardine L, Riedel A, Hegazy $\mathrm{AN}$, et al. Single-cell transcriptomics of regulatory $\mathrm{T}$ cells reveals trajectories of tissue adaptation. Immunity. (2019) 50:493-504.e7. doi: 10.1016/j.immuni.2019.01.001

226. Zeng Q, Sun X, Xiao L, Xie Z, Bettini M, Deng T. A unique population: adipose-resident regulatory $\mathrm{T}$ cells. Front Immunol. (2018) 9:2075. doi: 10.3389/fimmu.2018.02075

227. Kumar MP, Du J, Lagoudas G, Jiao Y, Sawyer A, Drummond DC, et al. Analysis of single-cell RNA-seq identifies cell-cell communication associated with tumor characteristics. Cell Rep. (2018) 25:1458-68.e4. doi: 10.1016/j.celrep.2018.10.047

228. Giladi A, Amit I. Single-cell genomics: a stepping stone for future immunology discoveries. Cell. (2018) 172:14-21. doi: 10.1016/j.cell.2017.11.011

Conflict of Interest: The authors declare that the research was conducted in the absence of any commercial or financial relationships that could be construed as a potential conflict of interest.

Copyright (C) 2019 Shi and Chi. This is an open-access article distributed under the terms of the Creative Commons Attribution License (CC BY). The use, distribution or reproduction in other forums is permitted, provided the original author(s) and the copyright owner(s) are credited and that the original publication in this journal is cited, in accordance with accepted academic practice. No use, distribution or reproduction is permitted which does not comply with these terms. 